\title{
ESTUDOS
}

\section{Educação e qualidade: repensando conceitos}

Marco César

Goldbarg

Palavras-Chave: qualidade total; educação.

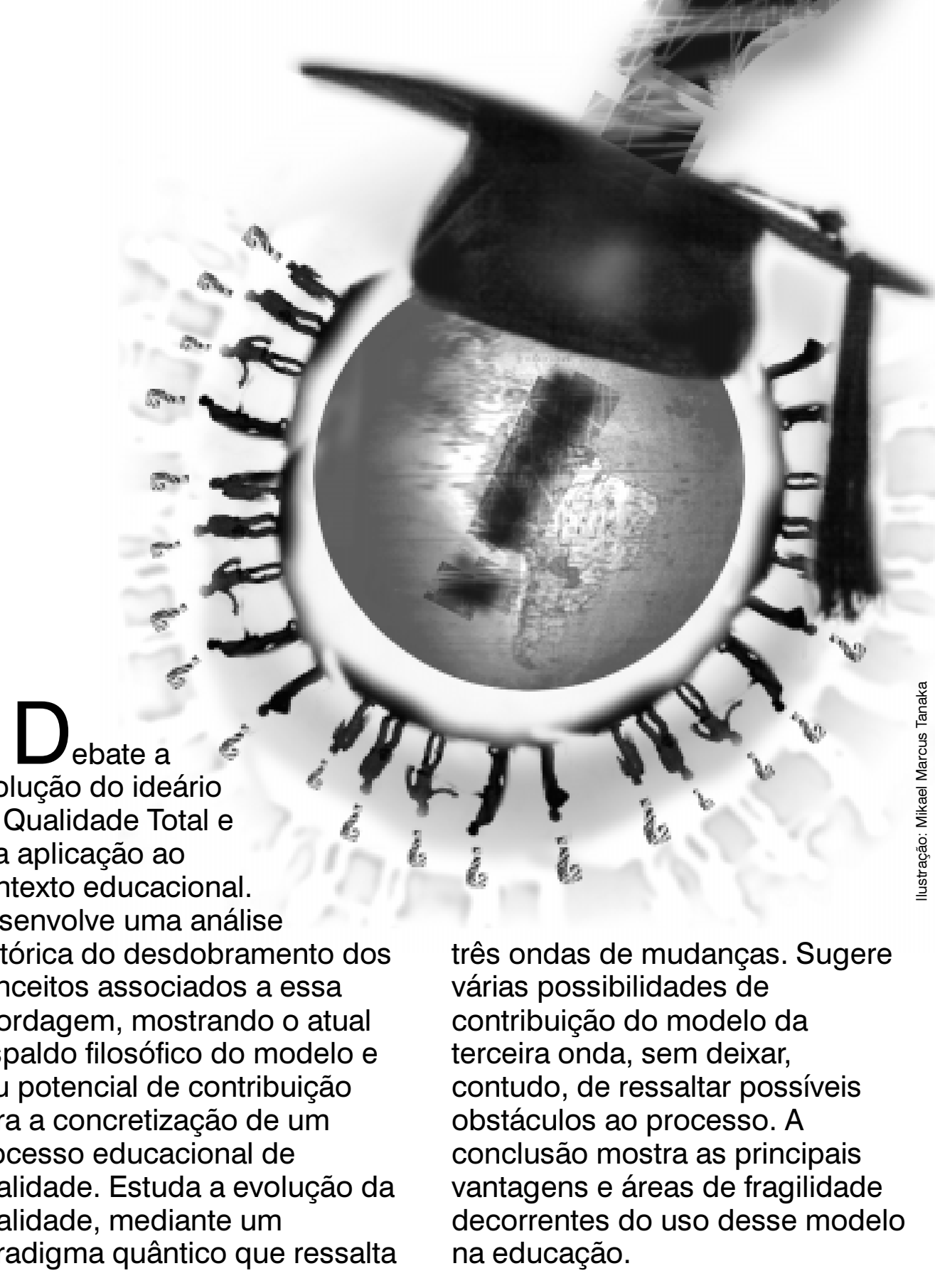




\section{Introdução}

Não é sem razão que o debate sobre a aplicabilidade do modelo da Qualidade Total (QT) à educação tem se intensificado nos últimos anos. A educação, entendida como a parte do fenômeno educacional, que é formalmente atribuída a instituições de ensino, tem enfrentado enormes dificuldades no contexto das mudanças do mundo moderno. Em praticamente todos os países, os sistemas educacionais estão sob uma enorme pressão. O sentimento de que as instituições educacionais respondem com lentidão aos reclamos e necessidades da sociedade é mais generalizado do que se pensa. Um exemplo disso está materializado especialmente no ensino médio. Como a articulação mais sensível do sistema educacional, o ensino médio está em xeque em vários países, inclusive nos do chamado Primeiro Mundo, vacilando entre $o$ atendimento das crescentes exigências do mercado de trabalho técnico e as imposições das universidades. Os enormes custos decorrentes das exigências tecnológicas e de infra-estrutura tornam inexoravelmente elitizados cursos superiores como Medicina e Ciência da Computação. Problemas se acumulam nas condições de acesso à educação de bom nível, na democratização do conhecimento e na justiça social. O que para muitos poderia ser resumido simplistamente como "um problema de verbas" é, na verdade, uma situação extremamente complexa, envolvendo muito mais que isso, englobando a essência dos desejos humanos, ou seja, valores e sonhos.

A crise, que tem um enorme lado perverso, possui também uma faceta interessante. A insatisfação tem obrigado os educadores a se permitirem repensar pontos antes intocáveis. Hoje, nada parece mais inamovível. Na busca de respostas que atendam aos novos ditames da realidade, o modelo de gestão baseado na filosofia da QT não escapou à análise. Num momento em que os antigos conceitos teimam em falhar e urge encontrar soluções, o chamado modelo da QT apareceu credenciado por uma aura de sucesso. Mesmo possuindo uma lógica aparentemente adequada apenas ao ambiente competitivo da indústria e do comércio, hoje se debate intensamente a aplicabilidade dessa proposta à área educacional.
A possibilidade de utilização das idéias da qualidade em educação rapidamente criou quatro grupos de pessoas: os encantados, os contrários, os desinformados e os céticos. Este artigo objetiva contribuir para o debate desapaixonado das reais potencialidades e limitações da aplicação da filosofia QT ao contexto educacional. Nosso objetivo principal será descortinar possibilidades de soluções que venham auxiliar o segmento educacional na superação de seus enormes desafios.

\section{As "ondas" da qualidade}

Antes de debater a proposta da QT em si, cumpre aprofundar um pouco o tema. É importante entender que a abordagem, que hoje assim se denomina, é o resultado de um elaborado processo de desdobramento e aperfeiçoamento de idéias. Esse processo vem ocorrendo ao longo de quase cinqüenta anos e comportou momentos significativamente diferentes. É indiscutível também que tais processos não se consolidaram de uma só vez, nem em uma só ocasião. Examinando o processo adaptativo da QT em face das múltiplas pressões geradas pelas mudanças de contexto desde o pós-guerra, podemos identificar três grandes impulsos ou reestruturações. Evidentemente esses denominados "impulsos" também não se consolidaram pontualmente, pelo contrário, foram se configurando de modo contínuo. O importante no caso é perceber que a mentalidade do modelo (na verdade, um metamodelo) da QT, apesar de preservar o mesmo nome ao longo do tempo, sofre três nítidas correções de curso. Esses impulsos ou "ondas" atuam em efeito cumulativo e em auto-referência, ou seja, incorporam os elementos do estágio anterior para aumentar e adaptar o potencial de resposta da abordagem. As mudanças são auto-ajustes direcionados ao atendimento da contínua entrada de novas exigências.

\section{A primeira "onda": 0 estilo japonês de pensar a qualidade}

Denominaremos primeira "onda" da qualidade um conjunto de conceitos e ferramentas que, praticados no início da dé- 
cada de 60 , deram origem a uma forma incipiente de gestão que procurava focalizar o processo produtivo na obtenção da qualidade. Essa forma de gestão, nascida no Japão, foi basicamente resultante da interação dos fatores constantes da Figura 1:

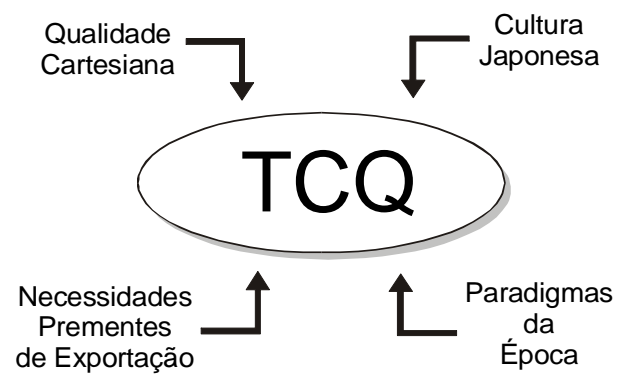

\section{Figura 1 - Principais fatores intervenientes} no nascimento do $\mathrm{TCQ}$

O primeiro ponto a entender no surgimento do Controle Total da Qualidade ou Total Quality Control (TQC) é que ele não foi originariamente pensado como uma filosofia de gestão. Seu eixo de atuação era ferramental. A ênfase estava centrada na disponibilização de ferramentas e procedimentos simples e racionais para a tomada de decisão. A parte ferramental estava apoiada na denominada qualidade cartesiana, composta por procedimentos estatísticos de controle do processo e uma metodologia de normalização e de solução de problemas. Os conceitos e ferramentas da qualidade cartesiana não podiam ser considerados uma novidade quando foram agregados ao TQC. Estavam disponíveis e integrados ao estado da arte para o controle da produção desde o final da segunda grande guerra, representando uma consolidação das técnicas de inspeção e controle da produção. Além das famosas ferramentas, técnicas e métodos da proposta, encontraremos em cada uma das denominadas "ondas" da qualidade uma maneira de pensar o conceito de qualidade. A discussão deste conceito é algo que surpreende por sua dificuldade, apesar da inocente aparência. De fato, cada uma das "ondas" que procuraremos aqui caracterizar acaba concebendo implicitamente o conceito sob uma ótica diferente.

Outro ponto notável no estabelecimento dessas fases é que a evolução da proposta acompanha didaticamente o crescimento dos modelos de concepção do fenômeno organizacional, mostrando uma extraordinária faceta adaptativa. Isso quer dizer que, apesar de ideologicamente "pouco engajado", o modelo acaba adaptado a uma lógica específica de mercado: a luta pela competitividade.

A primeira iniciativa, que lançou os fundamentos do atual movimento da qualidade, foi a qualidade cartesiana. Ela surgiu contextualizada no pleno vigor dos modelos mecanicistas do início do século. A qualidade cartesiana pouco se direciona ao aspecto da gestão em um sentido amplo. $\mathrm{O}$ conceito de qualidade sugerido pela metodologia reflete a predominância do conteúdo quantitativo de seus métodos e da dicotomia imposta pela mentalidade da época entre as práticas voltadas para a produção e as de gestão.

As necessidades sentidas pelas empresas japonesas na ocasião do surgimento do TQC estavam relacionadas à redução de não-conformidades e ao aumento da escala industrial. Fundamentalmente, o objetivo da qualidade cartesiana foi o de disponibilizar técnicas que permitissem a manutenção de um produto uniforme dentro de um cenário de produção em uma escala crescente (Garvin, 1988). Nesse sentido, nasce toda uma terminologia de "qualidade" associada à denominação dessa capacidade. A Figura 2 resume o processo da solução disponibilizado pela qualidade cartesiana dentro do contexto mecanicista de gestão.

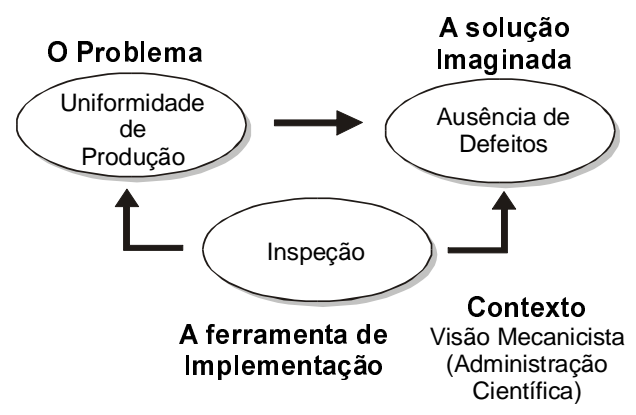

Figura 2 - Primeiro passo da qualidade: qualidade cartesiana

A prática da qualidade cartesiana realimentou o processo de autotransformação e incentivou o desenvolvimento de ferramentas que permitiram conciliar razoavelmente o objetivo econômico com a busca do aumento da eficácia do processo. As técnicas quantitativas disponibilizadas eram tão interessantes que logo transcenderam o contexto técni- 
co e passaram a influenciar a gestão. A Figura 3 resume o estágio inicial da contribuição da qualidade cartesiana, destacando-se o Controle Estatístico do Processo (CEP) como ferramenta de implementação da redução de defeitos.

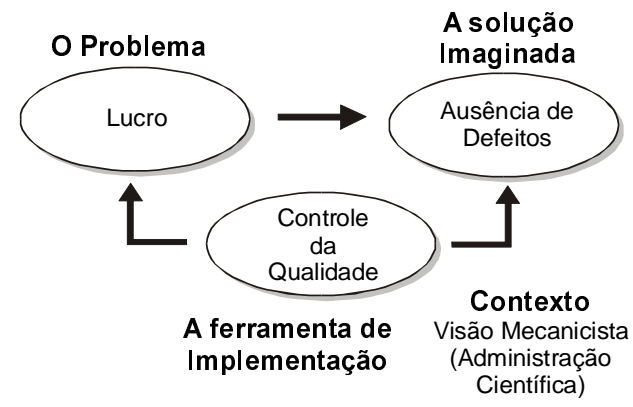

Figura 3 - Solução da qualidade cartesiana

A visão de que o conceito de qualidade não tem origem abstrata e sim representa uma solução para um problema colocado é bastante útil ao entendimento do aspecto evolutivo do modelo. O primeiro desses "problemas" a resolver foi o da uniformidade de produção, ou seja, o antigo objetivo da eliminação de variabilidade. A "ausência de defeitos" se constituiu a primeira solução julgada adequada para resolver esse problema. Como a concepção organizacional predominante na época era mecanicista, a proposta foi inicialmente operacionalizada por um conjunto de técnicas coerentes com a lógica mecanicista e respaldada pela administração científica: a "inspeção".

Obviamente, o ideário da qualidade não tinha qualquer compromisso com o modelo mecanicista, simplesmente ele era o vigente na época. A solução da busca da conformidade utilizando a inspeção logo é forçada por fatores econômicos a evoluir. Brevemente, a mentalidade de busca do defeito seria substituída pela de prevenção. O centro de interesse rapidamente é deslocado do resultado final para o processo. A postura de correção "pós-fato" é substituída pelo monitoramento e a identificação, através de métodos estatísticos, das condições que resultam em erros, inadequações e não-conformidades. Essa técnica também representou uma conveniente resposta às necessidades impostas pela solução "just-in-time", que começou a ser praticada pela Toyota, em 1948. Nesse contexto, o monitoramento ou "controle" adquire um papel fundamental como ferramenta operacional da execu- ção do objetivo de redução de não-conformidades. Quer através da inspeção, quer como um conjunto de técnicas mais elaboradas, o objetivo maior da qualidade cartesiana estava diretamente associado ao auxílio da fabricação de peças ou bens que atendessem a determinadas especificações e, como tal, ela seria praticada quase que exclusivamente dentro do domínio do setor técnico e por pessoal especializado.

Se a busca da qualidade cartesiana nunca foi um privilégio dos japoneses, o modelo TQC não surge apenas como uma aplicação da qualidade cartesiana aos moldes orientais, ele é mais do que isso. A novidade do TQC é que ele propõe a reorganização do conceito de qualidade herdado da abordagem mecanicista. O TQC traz consigo o gen de uma nova concepção do fenômeno organizacional. O TQC transcende completamente o contexto da qualidade cartesiana quando trabaIha aspectos típicos da gestão. Ele introduz a possibilidade de uma extraordinária inovação no relacionamento capital $x$ trabalho, se assim se poderia classificar $o$ revolucionário pacto social firmado tacitamente entre as organizações japonesas e seus funcionários (Deming, 1986, 1990). O acordo, suportado por várias peculiaridades da cultura japonesa e imposições ambientais, cria uma ponte para uma renovação das premissas técnicas da qualidade cartesiana. É essa proposta de relacionamento que permitirá um dos mais extraordinários sucessos na obtenção da participação dos funcionários, o principal responsável pelo "milagre japonês".

A metodologia empregada para a criação da proposta TQC contou com três níveis de atuação. O primeiro nível ou substrato básico foi a descoberta de um conceito simplificador que pudesse personificar e traduzir a capacidade da organização para responder às flutuações, exigências e ameaças do contexto. O conceito escolhido foi o de qualidade. É claro que a palavra foi alçada da qualidade cartesiana. Qualidade passou a ser a forma simplificada e prática para expressar ao corpo funcional a direção do sucesso. A crença de que a qualidade era algo indefinível ou de dificílima conceituação, a partir do TQC estava definitivamente ultrapassada. Por mais arrebatadora que fosse a idéia de qualidade e de como ela poderia significar um caminho para o sucesso, 
o sistema de gerenciamento do esforço organizacional teria de ser algo palpável e prático. Dessa forma, diretamente associadas à abstração do conceito, surgiram algumas novas idéias gerais e princípios operacionais que acabaram aglutinando-se em uma filosofia incipiente.

O segundo nível de atuação da proposta TQC foi a constituição dessa filosofia para a gestão. A "filosofia da qualidade" não nasceu pronta: foi estruturada na prática da busca da conformidade. A filosofia que começou a ser praticada no Japão, mesmo que prioritariamente voltada para a racionalização do processo, sabiamente não esqueceu de incluir a construção de laços duradouros entre o trabalhador e a empresa. Para o observador, que vê as coisas acontecendo do lado de fora, a parte mais visível do processo é a forma de gestão; contudo, lembramos que ela não passará de um amontoado disforme de técnicas se lhe faltar o suporte de uma consistente filosofia de ação. Por outro lado, a filosofia de nada adiantará se não resolver o problema certo, ou seja, uma filosofia sem uma articulação para a gestão é inútil. A Figura 4 mostra o que denominaremos "iceberg" ou "pirâmide" da gestão, ou seja, o desdobramento estruturado que leva os conceitos e mentalidades, mesmo subjacentes, a adquirirem o poder de atuarem na prática.

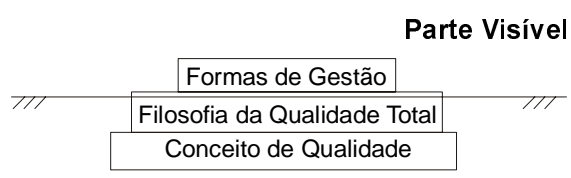

Parte Invisível

\section{Figura 4 - Hierarquia conceitual nas gestões de qualidade}

O "iceberg" ou a "pirâmide" são figuras úteis para o entendimento do papel dos três níveis de atuação da proposta de gestão pela qualidade. Sob o ponto de vista do "iceberg", vemos que existe uma parte do fenômeno de estruturação da gestão que é submersa, quase invisível. Sob a ótica da pirâmide, entendemos o aspecto hierárquico e articulado das idéias. Essas metáforas permitem esclarecer com mais facilidade por que a qualidade total não pode ser considerada genuinamente a forma de gestão. A figura é igualmente própria para ressaltar a importância do nível de ação filosófica. A qualidade total, diferentemente de um produto ou estágio de desempenho, é genuinamente um caminho para pensar o empreendimento. Sua consolidação conceitual ocorre em um nível de abstração muito superior ao da execução operacional, e teoricamente não vinculada a esse nível. $\mathrm{Na}$ visão do Departamento de Defesa Americano (Lam, 1991), a qualidade total é "uma filosofia e um conjunto de princípios que representam o fundamento de uma organização voltada para o aperfeiçoamento contínuo".

Nos primórdios da QT, os termos acabaram utilizados sem o devido rigor e, em algumas situações, a descrição dos princípios da filosofia acabou desestruturada ou desbalanceada, variando desde a apresentação de enunciados substancialmente ideológicos até a simples enumeração de recomendações operacionais. Hoje, não resta mais qualquer dúvida de que a QT não pode ser pensada como uma espécie de produto ou resultado final a ser alcançado (Charness, 1992). A dinâmica de atuação escalonada da proposta da QT possui uma série de vantagens:

- O conceito da qualidade, a base do "iceberg" ou "pirâmide", permite um meio uniforme e simples para a comunicação e direcionamento dos esforços. O conceito de qualidade é tão flexível que pode ser aplicado em todos os estratos de atuação praticamente sem qualquer alteração ou adaptação. Essa propriedade confere à abordagem a capacidade de desempenhar um papel extraordinário na simplificação do esforço de focalização da gestão. Através dele, é possível ligar objetivos estratégicos e operacionais em perfeita uniformidade semântica, integrando os mais altos níveis de planejamento a medidas práticas e locais de promoção da vivacidade e boa saúde organizacional.

- A disponibilidade de uma filosofia como a QT representa um avanço notável sobre outras abordagens, pois as dificuldades da implementação prática de um conceito é que fazem as pessoas afirmarem que "na prática a teoria é diferente". Podemos perceber a importância do afinamento filosófico com as ações práticas pelas seguintes palavras de John Akers (Sharman, 1992): "Estou cansado e farto de ir a fábricas e só ouvir elogios à qualidade e ao tempo de ciclo, e depois visitar clientes que só falam de problemas". 
A filosofia da qualidade vem sendo trabalhada com cuidado nesses últimos quarenta anos. São muito conhecidos os 14 pontos da "filosofia Deming" para a qualidade (Deming, 1986). Nela, sugestões práticas do tipo "eliminar slogans" se juntam a diretrizes extremamente abrangentes como a "manutenção da constância de propósitos". A abordagem de Deming ressalta, em essência, o aspecto revolucionário introduzido pelo TQC: o comprometimento é uma via de mão dupla. Sem um razoável caminho para a satisfação do trabalhador não pode haver comprometimento.

Na primeira "onda" da qualidade, a filosofia basicamente acabou sustentada por três idéias gerais que direcionaram o esforço de gestão, a saber:

- a melhoria contínua ou "kaizen";

- o controle estatístico da qualidade;

- a participação.

Através das três idéias-base e contando com a ajuda da cultura japonesa, o primeiro "iceberg" ou "pirâmide" de gestão consistente e operacional pôde ser edificado. A filosofia TQC destacouse por sua seriedade e, nos sistemas japoneses, transformou-se em algo bem real.

A ênfase na prática dos conceitos esboçados na "teoria" é patente na criação dos Círculos de Controle da Qualidade (CCQs) que, em última análise, eram reuniões de trabalhadores para discutir e solucionar os problemas da organização. Evidentemente, os CCQs representavam uma demonstração de participação e, eventualmente, comprometimento (Ishikawa, 1985). Mas ninguém imagine que essa ferramenta se viabilizou pela exortação ou ameaça. As condições que permitiram aos CCQs funcionarem bem estão associadas à verdadeira contribuição da prática do TQC e não ao formato ferramental dos CCQs em si. O sistema de emprego com estabilidade garantida, a promoção por tempo de serviço, o investimento em treinamento, a cooperação entre os sindicatos por empresas, a vinculação do ingresso no trabalho à conclusão dos níveis de estudo, e o alto grau de escolaridade e qualificação do trabalhador japonês estão na raiz desse sucesso. As muitas tentativas fracassadas de fazer funcionar os CCQs fora do Japão mostram cabalmente a diferença entre o conhecimento técnico do funcionamento de uma ferramenta e sua viabilização político-cultural. Esse exemplo demonstra cabalmente como é ilusório desfocar os problemas centrais da gestão e reduzi-los ao problema técnico. Podemos resumir a contribuição da primeira onda da qualidade nas seguintes idéias:

- evitar o erro é humano;

- as decisões gerenciais necessitam de fatos e dados;

- melhorar o desempenho não é vantagem, é obrigação;

- comprometimento só pode ser obtido em troca de comprometimento;

- trabalhar em "times" (equipes) tem muitas vantagens.

OTQC pode trazer ricos ensinamentos, se não desejarmos simplesmente copiá-lo.

\section{A segunda "onda" da qualidade: o foco no cliente}

Com o conceito de qualidade apontando para a conformidade, o foco do processo produtivo só poderia acabar centrado no bem produzido. A preocupação com a conformidade é evidenciada pelos princípios de Philip B. Crosby:

- qualidade é definida como conformidade a requisitos;

- a medida da qualidade é o preço da não-conformidade;

- o sistema que leva à qualidade é a prevenção; defeito.

- o padrão de execução é o zero

A primeira "onda" da qualidade sinalizou para a prática de técnicas e uso de ferramentas que construíssem um alto grau de higidez do tecido organizacional. Uma organização otimizada em seus processos e direcionada para produzir com confiabilidade exatamente aquilo que desejava produzir. O sucesso das empresas que colocaram em prática os três princípios medulares da incipiente QT se encarregou de popularizar a sigla TQC e de difundir seus métodos pelo mundo. Obviamente, a sigla nada significaria se não fosse a excelente adequação da estratégia do produto conforme, como uma resposta às exigências do mercado da década de 60. Mas nem sempre as coisas funcionaram bem quando os gestores ocidentais resolveram copiar os métodos japoneses. Pelo menos, dois problemas teimavam em acontecer:

- A continuação das mudanças nos padrões de exigência pressionou por so- 
luções mais abrangentes que as baseadas na estratégia do produto conforme.

- Era impossível replicar a solução japonesa para o pacto entre empresa $x$ trabalhador, e a participação do trabalhador ficava desassistida em incentivo.

O caso é que a concepção da proposta da qualidade era incrivelmente adaptativa. Os três níveis de articulação permitiam um número enorme de graus de liberdade e flexibilidade. A proposta poderia alterar conceitos, filosofias, ferramentas e metodologias com relativa facilidade, sem perder sua unidade e consistência lógica. Por outro lado, as alterações de contexto dificultavam igualmente a resposta de outros modelos para gestão... No final da década de 60, mostravam-se indispensáveis pelo menos três providências para que o modelo da QT pudesse continuar sua trajetória de sucesso:

- Havia de se repensar a possibilidade de obtenção de alto desempenho organizacional e vantagens estratégicas através do conceito de qualidade como atendimento de requisitos de adequação do produto. A razão dessa necessidade era cristalina, uma vez que o contexto de serviços sinalizava por um outro papel para os requisitos estritamente associados ao produto ou ao processo de produção.

- Havia de se pensar novos princípios para a filosofia de gestão, caso o conceito de qualidade fosse alterado.

- Havia de se desenvolver as técnicas e ferramentas necessárias à praticidade da abordagem, quando a nova filosofia de trabalho fosse desenhada.

Na década de 70, ocorre um crescimento exponencial no número de tarefas e surge a necessidade do tratamento global dos processos de produção ou de prestação de serviços. O contexto organizacional se torna tão complexo que as teorias de Adam Smith e Frederick W. Taylor se esgotaram completamente. A crise se instala na mentalidade mecanicista. A proposta da QT, equilibrando elementos da administração científica e humanista, está bem posicionada. Dentre as pressões que forçaram o reposicionamento das idéias do TQC e a constituição da segunda "onda" da qualidade, destacamos:

\section{A focalização no cliente}

A idéia do produto, conforme praticada no início da década de 60 , estava perfeitamente adequada à concepção de um mercado comprador, carente de produtos que simplesmente funcionassem. Na década de 70 , nasce lentamente uma nova figura de "comprador", cada vez menos "consumidor" e cada vez mais "cliente". Dentro das novas exigências que se foram consolidando, o aspecto operacional do produto passava a ser apenas um entre vários itens que comporiam o conceito sobre sua qualidade. Serviços como os de atendimento e vendas passaram a ocupar uma posição relevante na formação do conceito de qualidade, eventualmente até mais importante do que a da própria conformidade do produto em si. Se por um lado o comprador (Albrecht, 1990) foi conscientizando-se de que era ele quem sustentava financeira e psicologicamente a atividade produtiva, por outro a concorrência foi acirrando-se nesse sentido. A percepção de que um cliente é uma pessoa importante é antiga (Schneider, 1992), mas, para torná-la operacional, era indispensável poder. Não foi por altruísmo que as empresas passaram a procurar ouvir a voz dos clientes e projetá-la para o âmago dos processos produtivos. A reversão radical na expectativa da oferta e procura por bens e serviços criou o ambiente para o crescimento da força do cliente.

A grande novidade introduzida pelo foco no cliente foi a percepção de que a saúde organizacional não poderia ser mais garantida somente com um bom produto, uma vez que esse atrator (Senge, 1990) era incapaz de satisfazer plenamente o novo perfil do comprador, agora entendido com cliente. As idéias introduzidas pelo marketing representavam uma crise conceitual para o modelo de qualidade praticado na primeira onda. A necessidade de concentrar o foco no cliente traria sérias conseqüências para o processo de levantamento de necessidades e planejamento (Kern, 1993). Mas, demonstrando impressionante vivacidade, em poucos anos a filosofia básica da abordagem japonesa foi capaz de realizar a ampliação conceitual indispensável ao atendimento das novas exigências. $O$ deslocamento do foco do produto para a satisfação do cliente ocorreu de modo tão natural e rápido que Kaoru Ishikawa, um dos gurus da qualidade, afirmava no início da década de 70: "Qualidade começa e termina no marketing". Essa adaptação da proposta da qualidade foi tão impressionante que foi capaz de despertar ci- 
úmes em muitos dos gurus do marketing, que se sentiram quase "furtados" em suas idéias. Utilizando a metáfora da pirâmide da qualidade, podemos divisar, na Figura 5, a evolução do modelo:

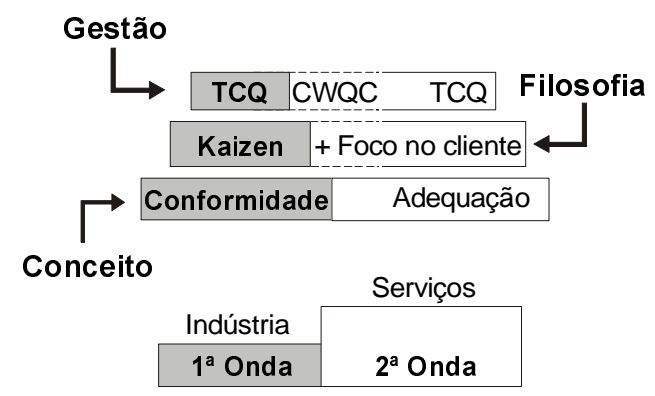

Figura 5 - A "pirâmide" da segunda "onda"

Na chamada segunda "onda" da qualidade total, o modelo de solução vai sofrer uma ampliação caracterizada pelos seguintes pontos:

- Ampliação do conceito de qualidade.

A qualidade passa a ser considerada como o atendimento das necessidades e expectativas do cliente. O novo entendimento do termo, além de colocar o cliente como o foco do processo produtivo, envolve o processo produtivo como um todo (Leighton, 1993). Passou a ser claro que o objetivo maior do esforço produtivo deveria ser a satisfação do cliente, e que esse atendimento deveria ser realizado não somente pela ausência de "defeitos" ou atributos negativos, mas igualmente pela presença de atributos positivos ou utilidade do produto ou serviço oferecido.

- A modificação nos princípios que constituem a base do modelo ou definem a qualidade.

Com o auxílio da metáfora da pirâmide, constatamos que uma alteração do conceito de qualidade implicará a automática alteração dos princípios da filosofia e do ferramental utilizado. Aos princípios da primeira onda somam-se na década de 70 , pelo menos, $O$ foco no cliente, a gestão sistêmica e a garantia da qualidade (BS7850).

Não foram apenas os aspectos da contingência de mercado que impulsionaram a segunda onda. Na linha da adaptação político-cultural, como já frisamos, o modelo é igualmente pressionado para mudar, especialmente nas experiências fora do Japão. As condições originais em que o TQC obtivera sucesso nunca podiam ser replicadas. Consultores japoneses foram contratados em toda parte do mundo para ajudar na implantação de sistemas TQC. Nessas experiências, coisas incríveis aconteceram, no sentido de "como fazer os métodos japoneses darem certo no Ocidente" (Stocker, 1993; Murata, Harrison, 1993; Chang, Labovitz, Rosansky, 1995). Esses programas foram apelidados de "transplants". O grande sucesso dessas iniciativas sempre ficou por conta da absorção das ferramentas da qualidade e o grande fracasso por conta de inadequações culturais no modo de fazer as coisas. Em não raras ocasiões, todo o conteúdo filosófico era perdido e o "programa" da qualidade reduzido à utilização das novas ferramentas dentro da antiga e tradicional mentalidade (normalmente mecanicista ou incompatível com a verdadeira filosofia da QT). Felizmente, muitas das experiências resultaram em sucesso. $\mathrm{O}$ impressionante nisso é que essas experiências de sucesso, na sua esmagadora maioria, não representaram "transplants". Pelo contrário, invariavelmente resultaram de uma adaptação bastante ativa dos princípios filosóficos. As organizações ocidentais que começaram a ter sucesso com a aplicação da qualidade total foram exatamente aquelas que cuidaram das condições da mudança mais do que das ferramentas.

Premidas pela variedade de situações, as adaptações do modelo japonês acabaram ampliando os princípios arrolados e trazendo uma impensada diversificação nas abordagens de solução. Em meados da década de 80 , as gestões baseadas na qualidade total já constituíam uma verdadeira sopa de letras (Harari, 1993). A ampliação do modelo é notável. O USA General Accounting Office escreve em seu relatório de maio de 1991 o seguinte conceito sobre o tema:

Gestão da Qualidade Total (TQM) é uma interpretação relativamente recente da arte de administrar. Seu objetivo é meIhorar a qualidade do produto ou serviço e aumentar a satisfação do cliente por meio da reestruturação das práticas administrativas tradicionais. A utilização do TQM é específica para cada organização que adota tal abordagem.

À medida que subconjuntos peculiares de princípios eram enfatizados no modelo geral, formaram-se variantes particulares de implementação prática que, em não raras ocasiões, receberam denomi- 
nações peculiares. Surpreendentemente, a versão tradicional japonesa esboça resistências à ampliação do conteúdo filosófico e inicia-se uma espécie de movimento de "contra-revolução", tendo à frente a Japanese Union of Scientists and Engineers (JUSE). O modelo japonês da segunda onda é representado principalmente pelo Company Wide Quality Control (CWQC). Essa versão caracteriza-se fundamentalmente por:

- incorporar a visão de Maslow (1970) para a motivação do trabalhador;

- empregar o método cartesiano de tomada de decisão, incorporando muito da abordagem de Taylor para a administração científica;

- promover a gestão através do uso do binômio controle de rotina e melhorias, buscando a previsibilidade e a competitividade;

- ser calcada no uso sistemático das ferramentas da qualidade e do PDCA (Shewhart, 1931).

Paralelamente ao modelo TQC defendido pela JUSE, inúmeras outras formas de implantar a QT floresceram (Bemowski, 1993; Johnson, 1993). Portanto, a segunda onda da qualidade se caracteriza pela flexibilização do modelo TQC e a evolução deste para uma mentalidade de busca da excelência, que recebeu contribuições de inúmeros autores, transformando-se no que alguns passaram a denominar "movimento da qualidade". O metamodelo passou, então, a caracterizar-se, pelo menos, pelos seguintes pontos:

- qualidade definida como adequação às necessidades e expectativas do cliente;

- expansão dos princípios da qualidade total, incluindo-se o foco no cliente, a gestão sistêmica e a garantia da qualidade;

- flexibilização do modelo com o aparecimento de uma série de siglas associadas à prática dos princípios da QT, ou às gestões baseadas na QT, siglas essas associadas às diversas ênfases praticadas nos princípios da filosofia;

- viabilização da aplicação da qualidade total em serviços;

- surgimento de uma série de novas ferramentas para o suporte à gestão, como o QFD, o Policy Deployment, etc.

Apesar do enorme avanço realizado pelos conceitos da segunda onda, alguns pontos permaneciam nebulosos no movimento, sinalizando para futuras áreas de fragilidade. A QT nesse estágio ainda pouco ajudava na condução de uma política de pessoal avançada, especialmente no Ocidente. O suporte na teoria de Maslow significava um avanço no sentido da administração científica de Taylor, mas ainda era insuficiente. A percepção da influência de fatores ambientais era igualmente deficiente. A busca desenfreada da competitividade e a predominância do atrator dos custos (Juran, 1986; Hart, Bogan, 1994), de certa forma uma herança antiga do passado histórico da proposta (Radford, 1922 apud Garvin, 1988), eram lugar-comum na maioria das versões praticadas. Enquanto a filosofia da QT esboçava a possibilidade de avanços significativos, no aperfeiçoamento do relacionamento da organização, com seus funcionários e a sociedade em geral, as aplicações reais da mentalidade da segunda onda da qualidade não se mostravam capazes de explorar completamente esse potencial. Nos sistemas da segunda onda, podemos distinguir uma certa inconsistência entre o aceno filosófico do metamodelo, no sentido de atingir até o direcionamento da vida das pessoas e a prática adotada no dia-a-dia das organizações. Nesse ponto, percebemos que a filosofia avançou mais rápido que as ferramentas disponíveis, e o sonho que começava a se esboçar perde o respaldo do concreto. Talvez a maior limitação das abordagens da segunda onda residia no modelo utilizado para o tratamento da complexidade organizacional. A expressão de Douglas McGregor é o indicador da mentalidade da racionalidade científica reducionista que orientava muitas das abordagens da qualidade na época da expansão do CWQC ao afirmar: "A maior parte do trabalho de um gerente é resolver problemas".

O gerente "solucionador de problemas" é uma visão simplória do papel de incentivador e promotor de condições para a cooperação e o estabelecimento de comprometimento. Essa concepção não é só medíocre como incompatível com a moderna educação, por exemplo.

\section{A terceira "onda": pensando 0 impacto social e a qualidade de vida}

Alguns autores, como Peter Drucker (1993), afirmam que dentro da nova sociedade que está em franco processo de consolidação, não existirá mais lugar para o 
trabalhador sem dignidade. Drucker faz diversas considerações sobre a importância do capital e da liberdade de mercado nesse novo mundo, mas igualmente afirma que "O desafio social da sociedade pós-capitalista será a dignidade da segunda classe: os trabalhadores em serviço. Como regra geral, esses trabalhadores carecem da educação necessária para serem trabalhadores do conhecimento". Por outro lado, a flexibilidade é hoje tão importante que Tom Peters (1989), com dramaticidade, afirma: "O objetivo não é ser excelente, porque 'ser' implica estagnação e não se pode ficar parado; as únicas empresas excelentes são aquelas que estão evoluindo rapidamente".

Antes de se darem conta, muitos administradores, voltados apenas para a eficiência e a eficácia organizacional, passaram a colher resultados frustrantes. Rapidamente essa estratégia deixou de garantir a continuidade do corpo organizacional em diversas situações práticas (Davis, 1992).

Toda a discussão anterior sobre qualidade, produtividade e formas de gestão, como já enfatizamos, está associada, em última análise, à busca de uma estratégia factível para a preservação econômica da continuidade do tecido organizacional. Uma vez que as práticas não respondem às necessidades, é indispensável encontrar novas respostas. A essência da loucura é esperar que, insistindo em fazer as mesmas coisas, os resultados mudem. Alterar as regras significa inexoravelmente alterar o caminho pelo qual as coisas serão feitas. Um novo caminho normalmente impõe novas ferramentas, novos modelos mentais e nova estratégia para a gestão. Redirecionar a forma de gestão não é simplesmente modificar as ferramentas ou a metodologia de trabalho, é repensar a forma de abordar o trabalho, ou, como já frisamos, é repensar conceitos e filosofias.

\section{A terceira evolução do conceito de qualidade}

A única hipótese possível para que o movimento da QT não sofresse os impactos dos últimos anos seria ele ter antecipado essas mudanças. Infelizmente, se isso tivesse ocorrido, o conceito de qualidade praticado pela segunda onda não teria sido tão adequado ao seu momento histórico. Resta apenas fazer a já tradicional pergunta: O modelo da segunda onda seria tam- bém adequado na ocasião da queda do muro de Berlim? Com o foco concentrado no cliente, seria bem razoável definir qualidade da seguinte forma: "Qualidade é a satisfação experimentada por um cliente ao desfrutar de um produto ou serviço" ou "qualidade é a totalidade de propriedades e características de um produto ou serviço que lhe confere aptidão de satisfazer necessidades implícitas e explícitas" (ISO 8402).

Conforme a American Society for Quality Control, "qualidade é a totalidade dos requisitos e características de um produto ou serviço que estabelecem a sua capacidade de satisfazer determinadas necessidades".

A busca do que é relevante para o cliente depende do atendimento de fatores ou dimensões que podem variar de pessoa para pessoa e de cultura para cultura. David A. Garvin, em seu livro Gerência da Qualidade (Garvin, 1988), apresenta oito dimensões da qualidade como um aspecto perceptível do produto que irá contribuir para a formação do conceito final de qualidade. Decomposta em dimensões, a qualidade pode ser melhor observada, alterada e planejada. É claro que falar em qualidade e não reconhecer o seu aspecto adjetivo multifacetado é, no mínimo, um engano lamentável. As visões que não percebem as dimensões adjetivas possivelmente utilizam o termo apenas como um "buzz word", encobrindo intenções menos abrangentes dentro de um respaldo verbal (Fellers, 1995). Utilizando o modelo de Garvin, podemos definir qualidade sob um ponto de vista razoavelmente modular e essencialmente relativo. À definição de qualidade como atributos ou conjunto de características, denominaremos qualidade adjetiva. Em nossa análise de adequação, restaria examinar quanto essa compreensão do conceito de qualidade ou qualidade adjetiva, como a estamos denominando, facilitaria a percepção de atratores profundos para a manutenção da vivacidade organizacional, ou, ainda, quanto a qualidade, vista sob a ótica adjetiva, estaria apta a ajudar na resposta ao momento atual.

Parece indiscutível que as oito dimensões de Garvin ou qualquer outro conjunto dessas especificações associadas ao produto não são suficientes para garantir o sucesso de uma organização. Mesmo considerando que a qualidade adjetiva 
seja alcançada pela gestão, tanto em relação aos clientes externos (eficácia) como em relação aos internos (eficiência), na atualidade é necessário algo mais para garantir saúde e vida longa...

O entendimento do que chamamos de "qualidade", através da descrição de uma série de requisitos ou dimensões adjetivas, possui um efeito colateral bastante perverso: permite uma simplificação tão forte que acaba eliminando da visão vários componentes do processo não diretamente associados ao produto ou serviço e que podem fazer diferença. Infelizmente esse foco pode mostrar-se míope e insuficiente em contextos mais amplos. Os gestores estão cada vez mais despertando para a realidade de que não são apenas os clientes diretos que determinam a sobrevivência de suas empresas. Em um contexto mais complexo, passa a ser indispensável a consideração dos resultados e contribuições do processo produtivo de todos os atores do fenômeno. Não são apenas os passageiros dos aviões que podem influenciar uma companhia aérea, nem tampouco são os compradores de papel os únicos que podem determinar mudanças no processo de fabricação desse produto. A difusão das informações e a crescente consciência de cidadania estão modificando profundamente a lógica da qualidade adjetiva praticada na segunda onda. O relacionamento da organização com a sociedade em geral pode, na atualidade, causar tantos problemas ou vantagens quanto causam os impactos gerados pelos produtos diretos. Obviamente, gerenciar esses tipos de interações é uma exigência mais refinada. Aparentemente, esses fatores podem apresentar-se como pertencentes à esfera do "quase ingovernável" e, portanto, para o gestor, serem pouco importantes. O fato é que, quando o contexto da gestão é complexo, uma focalização unidimensional pode ser insuportavelmente simplista.

O contexto educacional é um exemcutido e adaptado ao contexto da educação. Infelizmente esse debate escapa ao escopo do presente artigo.

2 Apesar da inegável "qualidade adjetiva" das bolas fabricadas pelas crianças de alguns países, elas não foram utilizadas na Copa do Mundo de futebol em 1994

3 Juran afirmou certa ocasião: "Eu não sei o que significa TQM. Eu nunca uso esse termo". (Quality Progress, v. 27 Ago. 1994). plório. Mesmo dentro da realidade empresarial existem inúmeros exemplos em que vários fatores "extraprocesso" devem ser cuidadosamente levados em conta. Preservação ambiental, qualidade de vida e contribuição social fazem parte da moderna atuação de sucesso, apesar de serem pontos não claramente vinculados aos focos da segunda onda.

Um último exemplo pode resumir facilmente por que não é mais suficiente atender plenamente ao usuário e obter lucro para garantir sobrevivência: por mais bela, bem acabada, equilibrada e barata que uma bola possa ser, ela não tem qualidade se foi manufaturada através de trabalho infantil. $\mathrm{O}$ interessante aqui é que o problema das bolas de futebol que são fabricadas por crianças transcende completamente o conceito da qualidade adjetiva ${ }^{2}$ Uma organização que não respeita os direitos de seus trabalhadores, apesar de poder teoricamente alcançar a qualidade adjetiva, jamais alcançará uma posição confortável e estável entre as organizações de sucesso. Esse é um exemplo em que a competitividade e o "estar bem" seguem rumos diferentes. Ao final do século XX, vemos que são necessários atratores menos imediatistas para garantir boa saúde organizacional. A estratégia gulosa de perseguir o lucro e uma posição de liderança no mercado não parece mais ser uma linha de ação tão "definitiva" para a sustentação da vivacidade a longo prazo. Muitas figuras importantes do movimento da qualidade recusaram-se peremptoriamente a admitir a necessidade de que o conceito de qualidade fosse ampliado para além do produto e que isso resultasse em um embasamento filosófico mais amplo (ver Quality Progress). ${ }^{3}$ Apesar das resistências, a proposta da QT concretizou a terceira resposta em direção à integração da gestão ao meio ambiente, englobando, além dos aspectos econômicos, os ecológicos e sociais.

Evidentemente, não estamos afirmando que o conceito de qualidade adjetiva é inútil, pelo contrário, é significativo o reconhecimento de que a qualidade possui diversas dimensões, quando observada pelo ponto de vista do cliente. Na raiz da qualidade adjetiva, está o início da consciência de que o futuro de uma organização depende de sua capacidade de corresponder às necessidades e expectativas e isso é significativamente diferente da proposta da 
qualidade cartesiana. Queremos ressaltar este ponto: em algum momento, o gestor que utiliza o conceito de qualidade adjetiva vai descobrir que necessita de aplicar princípios que não estão totalmente justificados pelo seu conceito restrito de qualidade. Pode sentir-se desconfortável ao perceber que deverá tomar algumas decisões que poderão até contrariar parcialmente a satisfação imediata do cliente externo, ou de suas estratégias de "controle", ou correrá o risco de perder viabilidade em médio e longo prazo! É igualmente desagradável notar que apesar de afirmar peremptoriamente que a prioridade é o ser humano (típico problema do TQC), seus conceitos de qualidade irão empurrá-lo para a otimização de processos, melhoria contínua, redução de postos de trabalho e foco no econômico. Na prática, a segunda onda da qualidade, focalizando-se no cliente externo, dá pouca importância aos investimentos fora desse eixo. Pior que isso é a constatação de que falta um respaldo mais profundo na abordagem para o tratamento, por exemplo, de situações de conflito entre as dimensões da eficácia e a qualidade de vida no trabalho. Essas deficiências podem ocasionar a emissão de sinais inconsistentes na liderança do processo (Samuel, 1994), o que produzirá desgastes insuportáveis. A Figura 6 mostra a origem do problema.

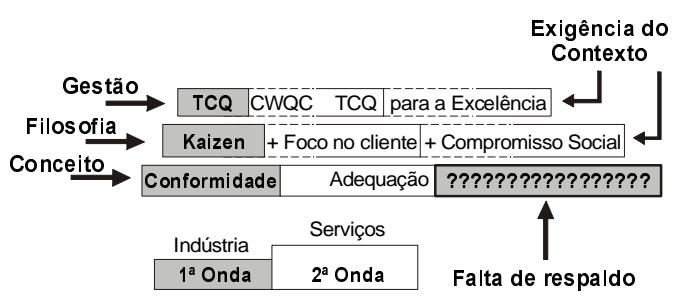

Figura 6 - A "pirâmide" incompleta

Para ampliar a concepção da visão adjetiva e corrigir a simplificação do atendimento do cliente via "product drives", surge a noção de impacto do processo produtivo. Para expressar essa necessidade, será feita aqui a distinção entre a qualidade adjetiva, ou a qualidade referenciada à adequação do produto ofertado ao cliente, e a qualidade substantiva, ou o que passaremos a denominar qualidade referenciada à ampla satisfação ou adequação do impacto do pro- cesso produtivo, incluindo-se as repercussões sobre:

- o uso dos recursos e emprego dos meios;

- os diversos clientes;

- os colaboradores e o meio-ambiente organizacional;

- o meio-ambiente ecologicamente definido;

- a ética de atuação.

Dentro da terceira "onda":

Qualidade não custa mais caro, custa muito menos; qualidade não é luxo, é necessidade; qualidade é sinônimo de ampla satisfação; a melhoria contínua finalmente atinge a vida do empregado; qualidade de vida faz parte da busca da excelência; o compromisso da organização com o funcionário não é menor que o do funcionário com a organização; as ações organizacionais devem buscar o desempenho sustentável.

À medida que se pratique um conceito de qualidade restrito, a filosofia acabará igualmente limitada (Winder, 1993) e a abordagem decrescerá de nível, correndo o risco de virar um "pacote". Essas visões díspares (Bonilla, 1995) que ora praticamente definem a proposta dentro do padrão ISO 9000, reduzindo a gestão pela qualidade à garantia da qualidade, ou imaginam o modelo como a solução de todos os males e problemas da humanidade, são perigosas.

A filosofia contemporânea da qualidade total objetiva basicamente dar o suporte filosófico para a implementação do entendimento do que seja uma organização de qualidade. Consideramos qualidade total como uma ampla e inovadora filosofia de gestão, por sinal uma das mais interessantes propostas de harmonização e condução das relações de trabalho. É claro que a QT não representa uma panacéia ou o fim do desenvolvimento das filosofias gerenciais; pelo contrário, apenas um estágio no aperfeiçoamento humano.

Para entendermos a magnitude da filosofia da qualidade total, temos de perceber sua dinamicidade e adaptabilidade. Trata-se de uma ampla estratégia para colocar a busca da excelência como ponto central dos negócios e atividades da organização. Como uma filosofia, é normalmente expressa por princípios. A prática desses princípios é que caracteriza a capacidade da ges- 
tão de atingir seus objetivos maiores. Apesar da sugestão da BS 7850, parte 1 , em relação aos princípios a serem adotados, dentre os mais aceitos temos: foco no cliente; foco no ser humano; melhoria contínua; gestão participativa; constância de propósitos; gerência de processos; poder na execução ("empowerment"); garantia da qualidade; trabalho em times (equipes); virtualização; gestão ambiental; orgulho pelo trabaIho. O metamodelo da qualidade, em última análise, sugere que gerir uma organização é ser capaz de realizar os seguintes ajustes:

- entre a organização e o produto (a dimensão da eficiência);

- entre o produto ofertado e o cliente (a dimensão da eficácia);

- entre a organização e os seres humanos (a dimensão da qualidade de vida);

- entre a organização e o seu meio ambiente (a dimensão da contribuição social).

A conformidade pressiona rumo ao contexto quantitativo e a boa técnica, rumo ao "fazer bem", destacando principalmente aspectos normativos e de especificações. A adequação direciona rumo ao levantamento de necessidades do cliente, à atenção do atendimento e à criatividade. A qualidade de vida aponta em direção aos fatores motivacionais e humanos. O impacto social ressalta o papel social da organização e sua contribuição para a preservação ecológica e o bem comum.

A Figura 7 resume a metáfora da pirâmide de hierarquia conceitual dentro da terceira onda. $O$ conceito de qualidade expande-se, dando suporte a uma série de revisões nos valores e objetivos do processo produtivo que, reunidos em um corpo ativo, constituirão a gestão pela qualidade total.

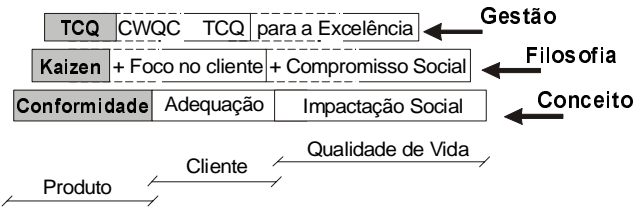

Figura 7 - A "pirâmide" completa

De uma forma geral, a gestão pela qualidade total poderá ser compreendi- da pelo conjunto de ações resumidas na Figura 8:

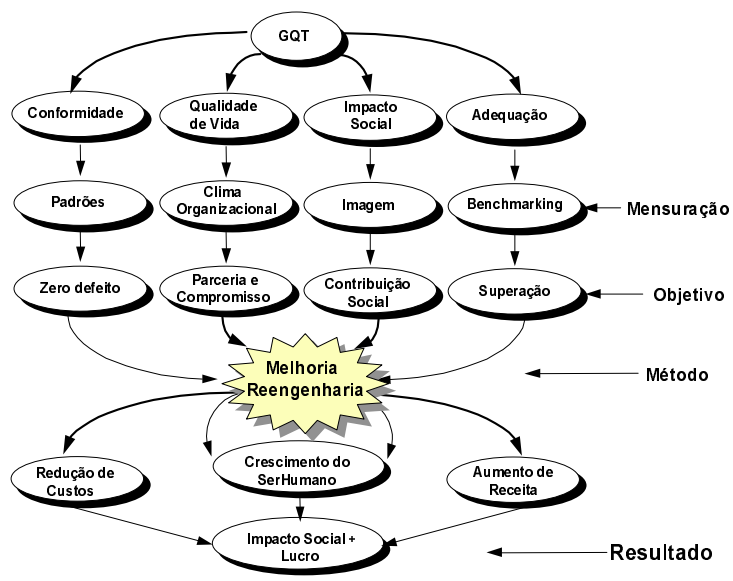

Figura 8 - A atuação da gestão pela qualidade total

\section{Qualidade total na educação}

\section{0 sentido existencial do compromisso com a qualidade}

Cada cabeça pode imaginar uma solução diferente para um mesmo problema, à medida que seu raciocínio seja polarizado por algum aspecto ou dimensão do caso. Quanto mais complexo for o problema, mais dimensões peculiares possuirá e, em conseqüência, mais provável será que ocorra uma distração no raciocínio. Existem dimensões mais atrativas ou mais evidentes que outras, o que pode acabar empanando a visão de importantes dimensões mais profundas. Não podemos falar em "qualidade na educação" ou em uma "escola de qualidade" sem sermos capazes de alcançar as dimensões mais profundas do fenômeno, perseguindo seu sentido existencial. Um ponto fundamental a entender nesse processo de descoberta é que qualidade e educação são lados de uma mesma moeda.

Qualquer visão limitante do verdadeiro escopo da educação é, em última análise, um fator de não qualidade. Uma Escola de Qualidade (EQ) deve ser vista e entendida em toda a sua pujança, diversidade e dinâmica. A principal instituição atuadora no processo educacional não pode ser pensada como um mecanismo, ferramenta, aparelho ou instrumento. Se uma abordagem mecanicista já é danosa em ambientes organizacionais menos complexos e exigentes que o educacional, que diremos quando aplicada a tão sofisticado proces- 
so? Apesar de o corpo da organização educacional não flutuar no espaço, estando, pelo contrário, submerso em uma sociedade que possui seus valores e cultura, uma Escola de Qualidade, como um agente (não instrumento) no atendimento das necessidades e expectativas humanas, tem compromisso maior com seus alunos, com a qualidade de vida, com a possibilidade de providenciar oportunidades para a construção de um mundo melhor. Uma escola só pode ser imaginada como um meio social de atendimento de necessidades e expectativas das pessoas. Qualidade na educação é uma dádiva que deverá ser voltada para todos (Nascimento, 1994). Definir o compromisso da educação é o primeiro passo para a qualidade.

Uma Escola de Qualidade deve ajudar na preparação para a vida em "lato sensu", mas não pode cair no engano de definir o que é "desejável" ou "prático", transformando-se em um projeto de difusão ideológica unidimensional.

Uma EQ é uma entidade que transcende o momento. Em conseqüência, o vigor analítico e crítico necessário à transformação da realidade será uma das essências da qualidade em educação. Da mesma forma que a humanidade transcende as ideologias, a escola deve ser capaz de transcender aspectos conjunturais e temporais. A humanidade não é uma grandeza temporal. Replicar e reforçar as coisas como são é preparar para o presente, é projetar o futuro como uma continuidade do agora.

É fato que romper com o agora é difícil, uma vez que as pressões que serão sentidas no futuro, configurando as necessidades e expectativas do próximo momento, ainda não chegaram. Além disso, mesmo no presente, a quem pode ser dado o direito de definir, com certeza, como as "coisas devem ser"? É basilar a compreensão de que as escolas são um dentre os diversos atuadores do processo de formação da competência humana. O compromisso de uma EQ não é formar e sim ajudar na formação do cidadão. É bom lembrar que a escola não é a única instituição capaz de ajudar o homem na jornada educacional... A família, o trabalho, os amigos, as igrejas e outras formas de organizações são co-partícipes desse processo.

O ser humano é o foco. É ele que se utiliza de todas as entidades para modelar, ele mesmo, sua proposta de vida. A uma $E Q$, portanto, cabe ajudar com suas me-
Ihores habilidades esse esforço individual. Alguns educadores ufanistas discursam, convencidos de possuírem uma "visão avançada", ao propor de boca cheia que o objetivo maior da escola é "preparar para a vida". Esse nos parece um objetivo extremamente óbvio em uma visão estratégica, tão óbvio que pouco espaço deixa para discussão. Por outro lado, é confuso, perigoso ou irrealista em uma visão operacional. O significado de "preparar para a vida" é, por si só, polêmico e pode acabar encobrindo objetivos nada nobres. Sugerir ao aluno as regras de sua sociedade (formais ou informais) pode ser considerado um modo de auxiliá-lo a se "preparar para a vida", mesmo quando essas regras não sejam, digamos, nada justas. Todas as instituições humanas projetam sua sombra replicante sobre o homem e isso é, na maioria das vezes, considerado como "preparar para a vida". Nesse caso, não caberia à escola, mais que a qualquer outra instituição, mesmo correndo o risco de perder o foco da praticidade imediatista, sugerir outras formas de visão? Até que ponto podemos definir que "preparar para a vida" é comungar de tal ou qual idéia? O papel da escola não seria exatamente despertar o homem para esse fato curioso? Mesmo consciente da possibilidade de se afastar do troféu do concurso da praticidade ou do engajamento maniqueísta, não faria parte da missão da escola mostrar que a realidade guarda idéias que nunca foram colocadas em prática? Ajudar o aluno a adaptar-se à sua realidade ou dar-lhe condições para mudar essa realidade, eis aí um dilema...

Talvez fosse mais útil perceber que a escola não pode tudo e não fará tudo. Mesmo que pudesse tudo, não poderia fazer tudo... E isso não é um problema de ser ou não um projeto de tempo integral... O que está em discussão é um papel delegado pela sociedade. Por outro lado, é especialmente importante entender que, mesmo sujeita a limitações de ordem material, temporal e filosófica, uma escola pode fazer melhor certas coisas do que qualquer outra instituição. Se, por um lado, a escola não pode e não deve se propor a "fazer tudo sozinha", por outro ela é indiscutivelmente habilitada para desempenhar alguns dos mais importantes papéis na educação. Uma escola de qualidade não se propóe fazer o 
papel de outros atuadores sociais e acabar falhando no seu próprio. Dentre todas as instituições da atualidade, a escola é uma das mais aparelhadas para ajudar as pessoas a pensar claramente, exercitar um julgamento independente, analisar e realizar crítica construtiva. Nesse ponto temos um foco a perseguir rumo à qualidade.

O empreendimento educacional tem de propiciar o justo retorno do investimento realizado pelo contribuinte ou pelos acionistas.

Reconhecer que no processo de educação existem interesses envolvidos que não estão estritamente relacionados com o ensino e a aprendizagem não é abrir mão da qualidade, é simplesmente ver o óbvio. Propiciar o justo retorno do investimento não significa conceder estrita prioridade para o retorno financeiro. Significa a busca da qualidade e do valor. Se uma escola é confundida com um "negócio como outro qualquer" ou idealizada como uma "vocação acima de todos os percalços", então todos acabam perdendo. Uma escola de qualidade não é um sonho irreal ou um pesadelo mecanicista; ela é uma entidade real e, formulamos votos, equilibrada. Uma escola de qualidade não pode temer o momento da prestação de contas, de tratar com as verbas, de justificar seus gastos. Prestar contas é uma necessidade gerencial, um direito da cidadania e um exercício de humildade. Em todos os casos é útil. Quem gasta mais tempo solucionando os seus problemas do que os justificando não teme o julgamento.

A escola deve ser um refúgio seguro para quem deseja uma educação emancipatória, independente, multifacetada e equilibrada, mas esses objetivos não podem implicar afastamento da realidade, falta de flexibilidade ou mobilidade.

A qualidade organizacional depende de um saudável equilíbrio entre prioridades e habilidades. O termo "equilíbrio" aqui só pode ser entendido de forma relativa e dependente de persistência. Os problemas, as pessoas e o meio ambiente se renovam diariamente. A qualidade de uma escola depende de uma adequada consciência por parte da gestão sobre o seu papel social, bem como de uma razoável autonomia e espaço para a tomada de decisão e atuação autônoma. A boa escola se aproxima de sua clientela e, mesmo mantendo a necessária isenção, procura integrar-se no momento contextual. Boa técnica educacional, habilidade gerencial e um projeto pedagógico alavancador dos melhores sentimentos e habilidades são indispensáveis.

Ainda dentro da discussão de seu sentido existencial temos de destacar uma outra característica das escolas de qualidade: $O$ compromisso solene com sua missão. Uma Organização Escolar (OE) é uma entidade fundamentada no compromisso. O papel educacional pressupõe um sólido compromisso com valores. Seus agentes recebem uma delegação nobre, e por isso o processo é vinculado à confiança. Para pais e alunos, o professor ocupa basicamente um cargo de confiança. A OE tem uma obrigação solene com seus alunos, pais, professores, funcionários e a sociedade como um todo: o de bem cumprir o seu importante papel. Mesmo arriscando resumir demais tão ampla missão, podemos dizer que educação de qualidade é aquela que ajuda a formar a competência do homem frente aos desafios do mundo, agindo na direção da cidadania, da transformação produtiva e do crescimento do ser humano.

A Figura 9 procura ressaltar os aspectos mais importantes desse compromisso com o aluno.

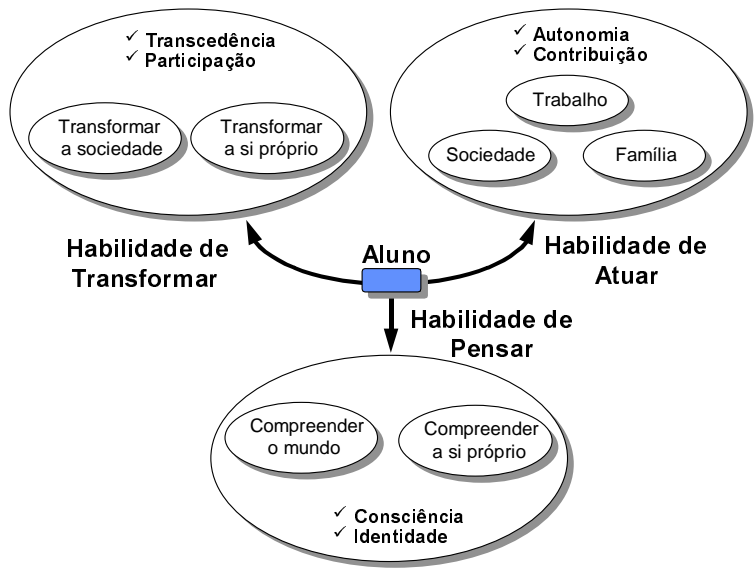

Figura 9 - $O$ papel da organização educacional junto ao aluno

\section{0 encontro entre a educação e a qualidade}

Para formarmos um quadro completo do que seria uma escola de qualidade, não basta examinar somente seus objetivos dentro do papel educacional: será necessário descer a detalhes operacionais das responsabilidades, atividades, tarefas e 
demais labores. Uma escola de qualidade só existirá se transcender a utopia da Castália e de suas escolas de elite (Hesse, 1943) e encontrar um caminho prático de implementação democrática.

$\mathrm{Na}$ busca de elementos basilares dentro desse processo de qualificação, claramente encontraremos um componente destacado: o ensino. Perseguir a qualidade em educação, por qualquer caminho que conduzamos o raciocínio, passará pela capacidade de bem ensinar (!) e pela habilidade dos alunos de aprender. Por mais estranha que seja a linha de pensamento adotada, é impossível falar em qualidade na educação sem falar em bom desempenho. Falar em desempenho não significa "manufaturizar" a educação ou aderir ao "positivismo", longe disso. Atingir alto desempenho depende de um conjunto de medidas e pré-requisitos materiais, mas não são apenas os fatores extrínsecos que contam. Para alcançar alto desempenho, são indispensáveis atitudes corretas, competência e, fundamentalmente, consciência do que se deseja. Para ressaltar a influência e a importância do alto desempenho, poderíamos negá-lo e observar o resultado.

Seria:

- admissível em uma escola a cultura de reprovação?

- possível uma OE de qualidade com uma péssima gestão?

- razoável admitir uma boa educação baseada em um ensino precário?

- possível pretender alta qualidade no ensino com professores sem a formação adequada?

De alguma forma, os conceitos de educação, ensino e gestão deverão harmonizar-se para que seja possível alcançar a tão desejada escola de qualidade. Essa interdependência era clara para Deming, que via na qualidade uma forma de adquirir o saber, especialmente aquele tipo de saber que ajuda a mudança: "A transformação deve ser conduzida por pessoas que adquirem saber profundo".

Debateremos esses temas de maneira a tornar essa interdependência entre qualidade e educação um pouco mais clara.

\section{Educação}

É impossível falar de qualidade em educação sem falar de qualidade e de educação. A pergunta que se coloca é: haveria ligação entre o nosso eixo temático e a quali- dade? Detalhando melhor: haveria suficientes ligações conceituais entre qualidade $e$ educação que justificassem aos interessados em educação um estudo da abordagem da qualidade? $O$ conceito de qualidade seria mais um adjetivo para a educação ou estaria relacionado, em sua essência, com toda a dinâmica de transformação envolvida no processo? Ao tentarmos examinar as correlações entre os temas, talvez o mais desejável seja esclarecer a questão: Podemos alcançar uma educação de qualidade sem possuir qualidade na educação?

Educar é transformar. Educar é despertar aptidões e orientá-las para o melhor uso, no sentido de produzirem satisfação. Sob diversos prismas, qualidade e educação possuem pontos em comum, a saber:

- Prisma do foco operacional

Tanto o processo de educação como o de qualidade têm como principal agente o homem, o próprio transformado. É o homem que adquire nova compreensão do mundo e as expressa através de novas estratégias de relacionamento.

- Prisma da consciência

Ambos os conceitos, qualidade e educação, objetivam alcançar a transformação através da conscientização e não do controle. Realmente a Educação é a própria estratégia da qualidade total. É somente pela educação transformadora que será possível alcançar o comprometimento, estágio final da participação.

- Prisma da satisfação e da qualidade de vida

Ambos os conceitos objetivam o preenchimento das necessidades humanas. Podemos considerar a educação como uma forma operacional de aumentar a qualidade de vida e promover a fitness organizacional. Esse último relacionamento e essa dependência são claros na visão de William Glasser (1992). É pela educação que o homem:

- situa-se dentro de seu contexto, distinguindo as suas necessidades e expectativas individuais das coletivas;

- aprende a interagir com o meio ambiente de forma a atender suas necessidades e expectativas e contribuir para o aperfeiçoamento desse mesmo meio ambiente;

- prepara-se para enfrentar as imprevisíveis mudanças que o contexto inexoravelmente sofrerá, mantendo a capacidade de adaptação e atuação ao longo de sua vida;

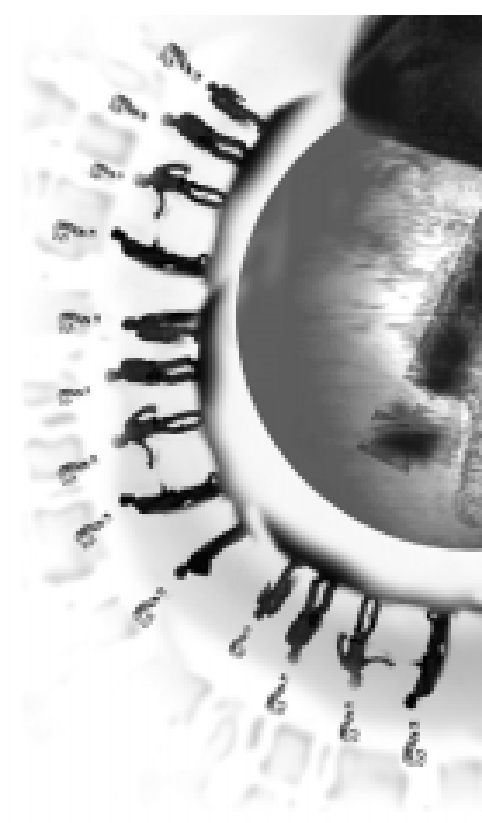




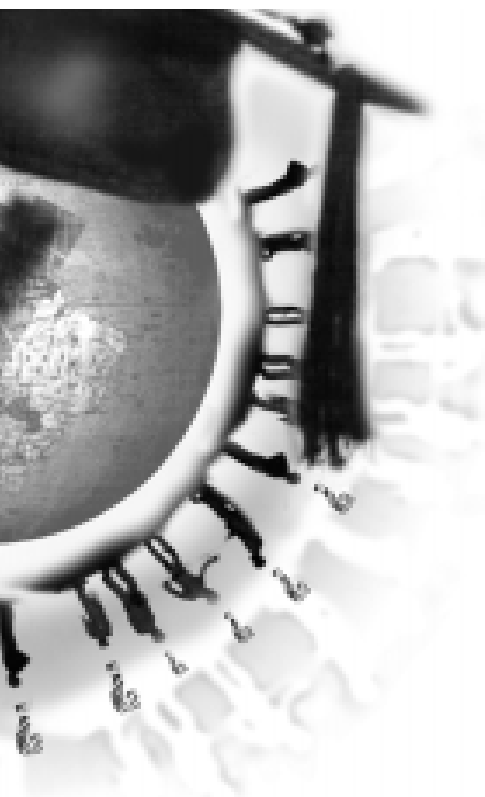

\footnotetext{
4 Ao citarmos Huxley, não estamos endossando seu epifenomenalismo.

5 Seria isso "preparar para a vida"?
}

- é capacitado a pensar, se desejar, além de suas necessidades e expectativas imediatas ou futuras de sobrevivência e prazer, refletindo um comportamento e um compromisso com a vida;

- adquire consciência e convencimento próprio a respeito da realidade;

- transcende a concepção materialista e imediatista e adquire valores superiores que lhe conferem a verdadeira humanidade.

Como afirma Thomas Huxley, ${ }^{4}$ "é somente pela Educação que um homem é levado a fazer aquilo que deva ser feito, independentemente de gostar ou não de fazê-lo". Huxley ressalta que a educação produz a consciência do papel do indivíduo na evolução do todo. Ela permite que o homem supere o estádio de suas necessidades e expectativas inconsistentes, imediatistas ou egoístas e se harmonize melhor com seu meio ambiente a longo prazo. ${ }^{5} \mathrm{~A}$ educação submete conscientemente as necessidades e expectativas de ordens inferiores às necessidades de ordens superiores, minimizando o desajuste global e apontando para atratores profundos de adequação. Pelo grau de consciência adquirida sobre a vida e seus relacionamentos, o homem educado opta por soluções globalmente mais estáveis e tem paciência e persistência para esperar pelos resultados de políticas de ação de longo prazo, e isso é o âmago do desenvolvimento auto-sustentável e da qualidade de vida.

Considerando uma visão do fenômeno educacional voltada para o crescimento do ser humano, os trabalhos de Glasser indicam a importância da promoção da qualidade de vida ser apoiada pela educação. Segundo Glasser, educar é, de alguma forma, "aumentar a qualidade de vida dos indivíduos e de toda a sociedade". Essa correlação entre qualidade e educação é uma visão interessante e que certamente pode ser útil no momento de realizar considerações pedagógicas. Uma gestão preocupada em utilizar o processo produtivo para aumentar a qualidade indiscutivelmente deveria estar envolvida com o compromisso da promoção de uma forte ênfase educacional. Dentro da visão da qualidade, o único meio de transformação cultural válido é a educação. Quando, para mover as pessoas no sentido desejado pela gestão, é indispensável intimidar, é porque o processo educacional falhou e já não existe a "qualidade" que pensamos preservar ou alcançar pela estratégia da insegurança ou medo. É no ponto em que a qualidade e a educação se encontram que coisas interessantes realmente podem começar a acontecer.

A qualidade depende de um processo de transformação e conscientização, enfim, de uma educação adequada e de sabedoria (ou saber profundo). A educação de qualidade é exatamente aquela que é capaz de atender às necessidades e expectativas do educando e representar um retorno adequado em conscientização e compromisso com a sociedade. É claro que, à medida que a qualidade transita do conceito adjetivo associado ao produto final para uma filosofia de vida, ou seja, para um conteúdo substantivo, a necessidade de meios coercitivos de "controle", para promoção da garantia da qualidade, vai se enfraquecendo. $O$ estabelecimento de relações prazerosas no trabalho é bastante sensível ao grau de liberdade e flexibilidade que a atividade de labor imprime e esta ao grau de conscientização do trabalhador. Realmente, os caminhos da qualidade e da educação estão interligados de uma forma inexorável, até sob o aspecto motivacional. Podemos dizer que educação e qualidade se encontram na promoção de uma vida melhor. Com base na idéia de Glasser, podemos ousar definir educação como um processo através do qual descobrimos que aprender a pensar e a aprender acrescenta qualidade em nossas vidas. A definição proposta destaca um outro aspecto não tão evidente em princípio: é difícil, para não dizer impossível, obter mudanças de atitudes ou de conceitos sobre assuntos que possam parecer dispensáveis ao estudante. Educação é um processo associado ao que há de essencial nas coisas. Qualidade não é igualmente algo essencial? Algo de valor ou desejável?

Outro aspecto interessante que podemos divisar no encontro da qualidade com a educação é a possibilidade de equilibrar a manipulação da "propriedade" do conhecimento. A educação, vista como uma forma de promoção da qualidade de vida, utilizará o conhecimento como uma produção de competência, de predominância individual, sem contudo excluir a influência social na definição dos "parâmetros" do que será reconhecido como qualidade de vida. Educação vista como um processo de 
promoção da qualidade de vida e da busca da excelência sinaliza para o equilíbrio da aprendizagem de conceitos e de fatos. Não resta a menor dúvida de que essa visão de educação não esgota o assunto, mas levanta um aspecto ligado ao lado prático e operacional do processo. Pode não ser completa, contudo aborda uma parte do problema de ensinar e transformar, que está fortemente ligado à dimensão motivacional.

\section{Ensino}

A prática da educação se desenrola do meio ambiente em direção ao sujeito, através do ensino. $O$ ensino resume a instrumentalização necessária à transmissão do conhecimento, base do processo de educação. Educação sem conhecimento e competência é puro verbalismo político. Para educar, é indispensável construir o conhecimento e, nesse aspecto, o ensino assume seu papel. $O$ ensino deve ser um processo compartilhado, logo depende profundamente do convencimento do aluno sobre a importância do conhecimento que está em discussão, ou seja, de sua capacidade de atender a suas necessidades e expectativas e de Ihe abrir alternativas para a melhoria de sua qualidade de vida. Ensino, estudo e aprendizagem são conceitos consideravelmente inter-relacionados. Objetivamente, o ensino, a dimensão mais fortemente associada à escola, busca consolidar um processo de transmissão e construção de conhecimentos que permita a aprendizagem, ou seja, a possibilidade de transformação. Apesar de toda a longa controvérsia que envolve a discussão da predominância entre fatores am-bientais e fatores herdados (Popper, 1975), parece-nos que a motivação básica para essa transformação é um fenômeno pessoal. Esse caráter individual do despertar dos potenciais e da consciência é mais um forte indicador para a consolidação de um ensino de qualidade. $O$ ensino de qualidade não pode ser realizado de forma padronizada ou normalizada, mas respeitando as peculiaridades do indivíduo. Outra conseqüência desse fato é a necessidade de se alcançar a melhor compreensão possível a respeito das carências e expectativas, presentes e futuras do aluno, para, utilizando o processo educacional, configurar condições para que elas possam ser supridas.

\section{Qualidade total e educação - novos conceitos}

\author{
0 fulcro do problema
}

Nos itens anteriores, debatemos múltiplos aspectos da inter-relação entre os conceitos de qualidade e educação. Neste ponto, gostaríamos de abordar o núcleo do problema atual da qualidade no ensino, aquilo que está causando mais desconforto dentro das instituições educacionais.

As pressões por novos rumos para o processo educacional estão reduzindo a fitness das escolas, especialmente das que não são capazes de acompanhar as mudanças.

O grande problema da educação moderna é que a nova realidade é para todos: governos, empresas, pessoas e... até escolas! Apesar de alguns pensarem que as escolas são eternas, isto é um argumento verbal. As OE, como organizações criadas pelo homem, não são um fim em si próprias. A necessidade do saber e da educação, esta sim, acompanhará o homem por onde ele for, faz parte de sua essência. A escola é uma forma de atender a essa necessidade, portanto, perfeitamente alterável.

Muitos imaginam que no Brasil as escolas poderiam ser melhores se houvesse uma concorrência mais acirrada entre o sistema privado e o estatal de ensino. A "luta" caracterizaria um ambiente de competição promotor de mudanças para a "qualidade". A idéia da "concorrência para a qualidade" é típica do modelo "War Game" da estratégia da competitividade. Dentro dessa proposta, seria uma boa idéia fustigar tanto as escolas particulares quanto as públicas, de modo que elas melhorariam o ensino no meio da espiral de luta pelo aluno. $O$ que essas pessoas esquecem é que a estratégia adaptativa defensiva é otimizadora. Será que, dentro dessa proposta, haveria lugar para a verdadeira educação, tão repleta de "ineficiências" filosóficas, de tempos próprios, de cuidado e carinho? Será que, praticando um modelo de guerra, as escolas estariam moralmente capacitadas a auxiliar na formação do cidadão altruísta? Este é o ponto central para a moderna discussão sobre novos 
modelos para a educação: as escolas, como uma solução para o fenômeno educacional, estão em xeque.

Aqueles que imaginam que a única ameaça às escolas sejam as outras escolas cometem o perigoso engano de esquecer que as mudanças do meio ambiente são historicamente as maiores ameaças à sobrevivência. Uma escola de qualidade preserva uma razoável capacidade de respostas imediatas, mas nunca se descuida de uma postura analítica e crítica em relação ao seu próprio papel. A qualidade na educação implica uma aprofundada visão de futuro. O cenário moderno está criando novas alternativas para a atuação formal no ensino. O desvinculamento entre o ensino e a educação é aprofundado na prática de diversas instituições. $O$ exemplo de maior sucesso no Brasil são os cursinhos preparatórios para o vestibular. A mídia e as empresas começam a reivindicar espaços específicos no ensino e mesmo na educação, pressionando pelo reconhecimento formal de seus treinamentos ou estágios supervisionados. A possibilidade da "escola aberta", onde o aluno com um auxílio tutorial construiria um conhecimento personalizado, é assunto de antigas discussões. Cursos supletivos são uma prática consolidada e representam uma ruptura com o ritual da educação, sinalizando, inclusive, o aceite social da possibilidade de a escola substituir seu foco na educação pelo foco no ensino.

Mesmo considerando que os argumentos anteriores não sejam tão importantes para justificar preocupação, é inegável que as pressões tendem a crescer. Na realidade brasileira, praticamente todos os beneficiários do processo educacional questionam a eficiência e eficácia do modelo atual. O problema, obviamente, não é o questionamento em $\mathrm{si}$, mas a realidade de que o modelo praticado não se tem mostrado capaz de oferecer boas respostas às dúvidas levantadas. É preocupante constatar que a capacidade de resposta dos sistemas educacionais tem-se evidenciado mais lenta do que a entrada de novas alterações, o que ocasiona um crescente distanciamento entre as necessidades descobertas e o processo de atendimento a essas necessidades. A construção das três habilidades de que trata a Figura 9 não é uma abstração; elas são uma necessidade real para o indivíduo. As pessoas precisam de ajuda para desenvolver essas habilidades e, se a escola não puder fazer isso, alguém fará!

Nesse contexto de debate, obviamente, a questão do trabalho se projeta diretamente sobre o papel da escola. A redução de empregos não é um fenômeno cabalístico, perverso ou misterioso, mas representa o descompasso entre o crescimento econômico e o crescimento tecnológico. Essa mudança nas regras é, sob nosso ponto de vista, um dos resultados da aplicação a longo prazo da perversa "lógica da competitividade". Com o foco centrado em objetivos pouco cooperativos, tais como a conquista de fatias crescentes da clientela, e utilizando estratégias de otimização e eliminação de "redundâncias", as organizações acabam vítimas de sua própria mentalidade de guerra. Uma guerra selvagem em que vale a lei do mais forte, mas que, longe de preservar os mais "capazes", a todos mata. Prisioneiras de uma escalada de especialização, as organizações acabam sem possibilidades de carrear recursos para a promoção da qualidade de vida no trabaIho, perdendo preciosas oportunidades para auxiliar no estabelecimento de uma realidade mais humana. A redução dos empregos é um fenômeno de abrangência mundial que aponta para uma grande falta de compromisso entre o mercado de trabalho e o homem e, nesse sentido, cava sua própria sepultura. Ressalvadas as diferenças regionais, a economia tem se expandido menos que as possibilidades tecnológicas, de modo que a produtividade se tornou para as empresas um fator determinante de adaptabilidade. Apesar de, na maioria dos casos, serem justas, as exigências e conquistas trabalhistas acabam, nesse cenário desfocado, tornando-se "redundâncias" ou sérios obstáculos aos objetivos competitivos. É o cenário e sua mentalidade de confrontação contínua que tornam os seres humanos mais expostos ao deslocamento ocasionado pelo avanço tecnológico.

Numa mudança contextual é sempre assim; alguns pontos avançam e outros recuam; alguns conceitos surgem e outros desaparecem. É nesse momento que a estratégia da fitness (Goldbarg, 1999) mostra sua maior utilidade. A escola do terceiro milênio não pode desconhecer essa evolução do mercado de trabalho. A dimensão do pensamento é a própria dimensão 
da crise. Pensar é questionar, avaliar, compreender, criar, etc. A dimensão da transformação se acelera dia a dia. As mudanças encurtam seu ciclo de vida e alargam o comprimento do passo. No âmago da discussão do problema do emprego e da empregabilidade, estão o papel do próprio trabalho e o embate das mentalidades e ideologias no campo da realidade factível. As ideologias, na prática, acabam todas muito parecidas para os trabalhadores. $O$ trabalho possui, pelo menos, três grandes funções, a saber: realização dos potenciais das pessoas; produção de valor agregado; maximização da sinergia.

Através do trabalho, as pessoas podem buscar, além da satisfação de suas necessidades imediatas, valores maiores, como a auto-realização (McGregor, 1980). O trabalho tem um importante papel no desenvolvimento de talentos e na realização de potenciais. O retorno social do trabalho é obviamente a contribuição do trabalhador na agregação de valor a um produto ou serviço. O desenho do processo produtivo tem um significativo impacto na qualidade de vida do trabalhador e, em última análise, na possibilidade de ele buscar seus valores maiores. Um exemplo da influência do desenho do processo produtivo sobre o homem é o trabalho em "times" (equipes). Esse desenho de atuação permite a maximização da sinergia dos sistemas produtivos e da sociedade em geral, bem como para o início da construção de relações sociais mais justas e agradáveis.

Na dimensão da transformação do indivíduo, encontramos as raízes dos maiores problemas para a escola. $\mathrm{O}$ adágio "Médico, cura-te a ti próprio" ou o pensamento de Ralph W. Emerson, "Todos os homens vangloriam-se da melhoria da sociedade, e nenhum homem melhora a si próprio", são a expressão da perplexidade que as escolas enfrentam: elas também devem mudar, sob pena de tornarem-se incapazes de ajudar na mudança dos indivíduos. Hoje, exige-se mais das escolas do que se exigia no passado. As análises que imputam a razão da crise da educação às causas locais são, no mínimo, míopes. Como causas locais, podemos citar: descaso das autoridades, falta de um política consistente de investimento, desmotivação dos alunos, dos professores, etc. Podemos ter certeza de que esses problemas estão longe de ser a causa central do que está acontecendo. As dificuldades que atazanam as instituições educacionais ao redor de todo o mundo são um resultado de causas mais profundas e menos aparentes. Em muitos países em que o volume dos problemas sociais e a quantidade de recursos destinados à educação são completamente diferentes dos da nossa realidade, temos também um setor educacional em crise. É preocupante quando existe uma progressiva perda de correlação entre o sucesso na vida profissional e a necessidade de apoio do sistema de educação formal. O real problema acontece na dimensão da perda de utilidade. Se considerarmos que problemas semelhantes possuem uma razoável possibilidade de admitir soluções semelhantes, então será bastante interessante examinar se as soluções praticadas no contexto empresarial para recuperar a fitness perdida podem ser aplicadas ao educacional. Mesmo admitindo uma enorme diferença no contexto cultural e político, seria admissível questionar a possibilidade de pensar em utilizar as estratégias de adaptação da QT na educação.

"Mas as coisas são muito diferentes na educação!", pode alguém afirmar. Para essas pessoas respondemos apenas com o famoso: "E viva a diferença!"

O convencimento de que a educação não poderá ser reduzida a um negócio (o ensino talvez...) por sua natureza peculiar é um consenso entre os educadores. Cremos que ninguém em sã consciência pretenderia simplesmente "transplantar" soluções empacotadas ou mesmo a cultura do "negócio competitivo" para a educação, porque elas não funcionariam.

E por que não funcionariam? Porque existem diferenças profundas como as seguintes:

- o contexto educacional é mais sofisticado e complexo;

- os impactos sociais da atividade produtiva educacional são um dos mais importantes aspectos do fenômeno;

- os "clientes" possuem necessidades e expectativas extremamente sofisticadas e conflitantes;

- os ciclos de vida são contados dentro de outras escalas;

- existe um outro nível de envolvimento emocional em jogo: o do crescimento da alma humana e não somente de sua satisfação dimensional.

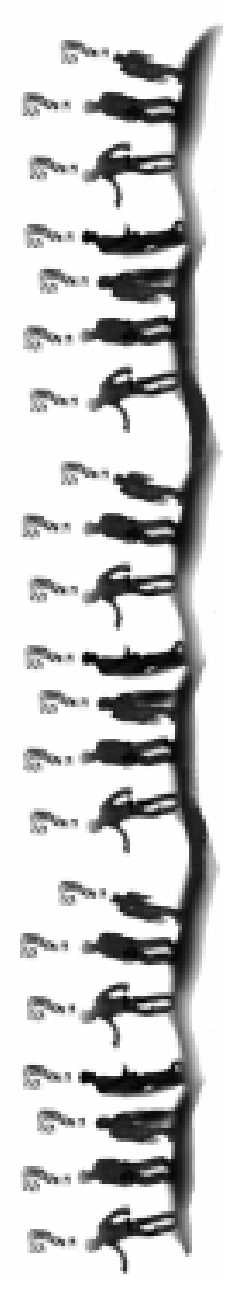




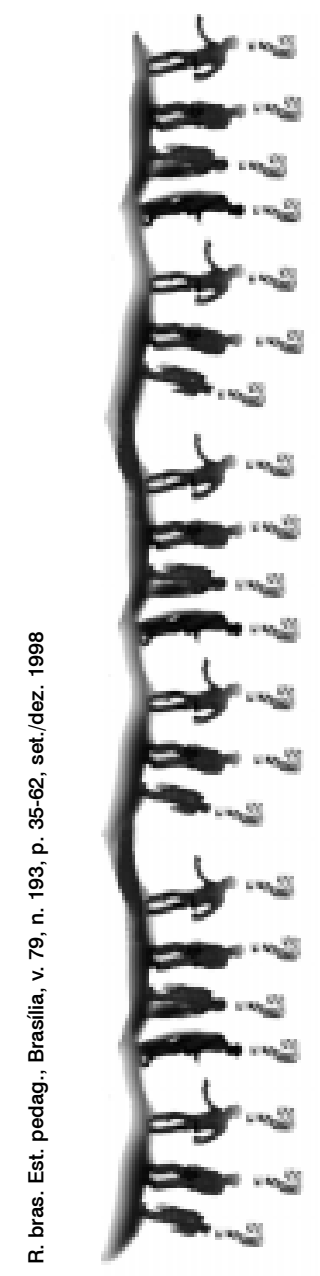

Inúmeros conceitos como "não-conformidades", "retrabalho", "satisfação", "clientes", etc, possuem uma interpretação diferente da que apresentam na abordagem industrial.

As diferenças não devem, todavia, impedir nossa visão sobre os pontos em comum, que, nesse caso, são profundos e básicos. Devemos igualmente lembrar que o relevante para a adequação de um modelo de solução não são os valores das variáveis ou o sinal de seu relacionamento e sim a natureza do fenômeno. "Em educação cada caso será sempre um caso" afirmam alguns, como se isso fosse um argumento que inviabilizasse a abordagem da qualidade (seria isso uma referência aos processos normativos da qualidade?). Não temos aqui nenhuma novidade, o mesmo acontece na realidade dos complexos sistemas empresariais.

O problema das escolas é, como de resto de todas as organizações, o problema da adaptação diante das mudanças. Antes de tentar ajudar seus alunos a aprenderem a aprender, ela mesma tem de ser capaz de fazer isso. Quem pode ensinar o que não sabe? Para se adaptar, a entidade educacional pode desenvolver diversas estratégias. Mesmo reconhecendo que existem vários caminhos para realizar a recuperação da fitness, vamos examinar a utilidade da abordagem da QT. É com a noção da necessidade de "uma solução" que nos animamos, mesmo reconhecendo que o desafio não é simples, a responder a, pelo menos, dois questionamentos:

1. A comprovada capacidade da filosofia da QT em lidar com a mudança poderia ser também útil no contexto educacional?

2. O metamodelo da QT poderia contribuir para o aperfeiçoamento da gestão da educação?

As duas perguntas anteriores colocam os pontos cruciais da utilização de um modelo. A primeira examina a compatibilidade entre a lógica do modelo e a lógica do problema. A segunda aponta para a necessidade de uma adequação prática e operacional entre o modelo e as peculiaridades do contexto. A primeira pergunta coloca em questão a adequação ideológica e a segunda, a adequação ferramental e operacional.

\section{A lógica do metamodelo da qualidade total}

Reconhecida a similitude entre os contextos, pelo menos no que diz respeito ao fato básico do enorme problema gerado pela desestabilização das necessidades da modernidade, vamos tentar responder à primeira pergunta analisando a adequação da "lógica" de atuação da QT. Inicialmente, detalhamos a evolução do metamodelo exatamente para que o leitor pudesse perceber a essência do modelo da QT. Em derredor dessa abordagem, existe hoje uma enorme cortina de fumaça onde nem sempre é fácil divisar a verdade. Pelo exposto, procuramos demonstrar que os melhores sistemas de QT objetivam:

- definir um objetivo simplificador para a gestão através do conceito de "qualidade";

- estabelecer uma série de prioridades de atuação, estritamente vinculadas ao contexto que preside a ação. Essas prioridades são materializadas através de princípios;

- aplicar os princípios através do uso das melhores técnicas disponíveis, direcionando os processos da organização para garantirem os quatro ajustes descritos anteriormente.

O "modelo" preconiza que toda a atenção dos processos de agregação de valor a um bem ou serviço deverá estar focalizada no atendimento das necessidades e expectativas do objeto final do processo. A GQT é fundamentalmente participativa, descentralizadora e voltada para o crescimento do ser humano. $\mathrm{Na}$ terceira "onda", os sistemas da qualidade sinalizam para a importância da contribuição social, do respeito à ecologia, e da atuação ética e honesta.

Essa é a lógica da QT! As ferramentas e técnicas da abordagem obviamente não são o fulcro do sucesso ou representam qualquer novidade extraordinária (Judd, 1995). Quando nos referimos à "qualidade em educação", estamos pensando basicamente em dois segmentos desse conceito. O primeiro, adjetivo, associado aos aspectos e às dimensões peculiares a cada envolvido no processo, e que representam o julgamento personalizado e individualista do valor do bem ou serviço. 
Qualidade adjetiva - capacidade de a instituição educacional auxiliar os alunos no despertar de seus potenciais e na construção do conhecimento.

Qualidade em educação não é só algo que possa ser avaliado apenas pelos denominados "clientes" diretos, por muitas razões (Goldbarg, 1999). Um segundo aspecto do conceito envolve mais do que os adjetivos: engloba a própria essência do fenômeno, implicando a necessidade de forte percepção social e política dos fatos. Denominaremos essa dimensão de substantiva.

Qualidade substantiva - capacidade de a instituição educacional de atuar como agente alavancador de mudanças pessoais e sociais que promovam a qualidade de vida.

Outro aspecto importante para entender quando examinamos a essência da abordagem é que a QT não é uma filosofia utópica. Ela não é baseada na exortação. Suas ferramentas fazem sentido. Ao examinarmos a possibilidade de emprego do modelo da QT para direcionar as ações de gestão no contexto educacional, estaremos interessados, em última análise, em saber da utilidade das suas premissas no processo de mudança e busca de excelência e da adequação da metodologia de transformação sugerida.

Não seria adequado à educação:

- o desenvolvimento de uma mentalidade e atitude adequada a uma gestão eficaz e eficiente?

- a prática de uma gestão baseada em uma série de princípios éticos?

- o aumento do comprometimento dos funcionários e professores com os objetivos da educação?

Seria possível:

- a utilização das mesmas técnicas que foram empregadas no contexto industrial?

- o aproveitamento das experiências vivenciadas em empresas?

- a adequação da abordagem à dinâmica e à realidade da prática educativa?

No primeiro conjunto de questionamentos, o que está em jogo é a avaliação da sensibilidade do fenômeno educacional à gestão. Dentro desse primeiro blo$\mathrm{co}$, a solução é relativamente simples. Observamos anteriormente que o fenômeno educacional, por sua complexidade, é muito sensível à competência de condução. Essa dependência, aliada à necessidade de um constante crescimento na performance, aponta naturalmente para a solução pela qualidade. Sob o aspecto do potencial de ajuda e das necessidades específicas, a resposta para o uso da QT é um evidente e sonoro sim. Uma educação de qualidade precisa de uma gestão de qualidade.

No segundo bloco de colocações, o fulcro seria avaliar a possibilidade das técnicas desenvolvidas para o contexto produtivo serem assimiladas em um outro contexto, com características sociais e culturais tão diversas. Se é indiscutível que uma educação de qualidade deva estar apoiada sobre uma forma de gestão avançada, o mesmo não ocorre em relação à escolha da QT como essa forma de gestão. As restrições impostas à gestão no contexto da educação não criariam tais peculiaridades que obrigariam atitudes e crenças incompatíveis com as praticadas na QT? A diferença da realidade política e cultural dos contextos não inviabilizaria a transferência de experiência adquirida? A educação poderia ser considerada um caso à parte, uma espécie de "exceção"? Mesmo que não fosse um caso tão à parte assim, as técnicas que lograram sucesso em incentivar e apoiar os trabalhadores do setor industrial seriam úteis para os funcionários de uma escola ? A visão sobre a melhoria da qualidade de vida, o "empowerment", a gestão participativa, etc, seriam aplicáveis? Por que sim? Por que não?

No aspecto da utilizabilidade, devemos tomar muito cuidado antes de uma conclusão. Em relação ao contexto, pelo menos, sabemos que os novos paradigmas da educação são absolutamente semelhantes aos enfrentados pelas organizações produtivas, envolvendo:

- modificação do foco do processo de prestação de serviço;

- novas demandas;

- interferência de fatores sociais e ecológicos;

- maior participação do "cliente", etc.

É nesse momento que a compreensão do potencial da terceira "onda" se torna indispensável. É dentro dessa proposta que encontramos a possibilidade de tratar os aspectos políticos e sociais do fenômeno educacional e realmente viabilizar sua contribuição para a melhoria do processo. Vários e intensos esforços foram e estão sendo desenvolvidos, visando viabilizar a utilização das técnicas desen- 
volvidas pela qualidade total no contexto da educação (Hittman, 1993; Salmon, 1993). Também parece claro que nem tudo são rosas nesse caminho (Axland, 1992). Se, por um lado, alguns bons resultados são reportados, por outro, permanecem pontos ainda em aberto (Caplan, 1992). O tema QT na educação tem sofrido várias abordagens, o que dificulta ainda mais uma análise conclusiva de resultados (Schargel, 1993).

É interessante que, mesmo sem denominar os programas como de "qualidade total”, vários países estão adotando contínuas modificações na forma de gestão educacional que estão perfeitamente contempladas pela "lógica" que apresentamos anteriormente. Aliás, muitos programas denominados de qualidade total no contexto industrial e de serviços no Brasil são menos aderentes à "lógica da qualidade" aqui apresentada do que vários dos sistemas europeus de educação.

Se, pelo menos dentro de um grande quadro, não são visíveis as diferenças tão extraordinárias que afastam ou impossibilitam a aplicação das idéias da QT em educação, nem tudo está perfeitamente esclarecido. Existem ressalvas e dificuldades reais de implementação. Ninguém se engane pensando que, com uma boa adaptação de um sistema da qualidade de uma indústria ou de uma prestadora de serviços, as coisas estarão resolvidas. O contexto possui algumas traiçoeiras peculiaridades que impedem, por exemplo, que exista hoje um padrão ISO de certificação da qualidade para escolas... Apesar de a filosofia de atuação da QT ser extremamente flexível e eticamente irrepreensível, suas formas de implementação podem acabar, na prática, enrijecidas e focalizadas em considerações mais operacionais. A QT concede ao gestor, além dos indicadores econômicos, vários $e$ amplos instrumentos de busca da contínua adaptabilidade, todavia não pode nem deve definir rigidamente como esses instrumentos serão escolhidos ou utilizados. Seria natural supor que uma experiência de sucesso para a QT pudesse ser uma ferramenta tão generalizável como são seus princípios, mas não é. É exatamente nesse ponto que surgem algumas dificuldades sérias: não problemas artificiais impostos pela mentalidade reacionária, mas problemas reais. $O$ fato é que existem mesmo alguns conceitos que têm de ser rediscutidos e não somente adaptados, se pretendemos utilizar a experiência da QT obtida no mundo da indústria e do comércio. Podemos resumir as dificuldades de aplicação dos sistemas de gestão baseados na QT na área de educação em três campos, a saber:

\section{Dificuldades devidas aos aspectos sociais do contexto educacional}

O sistema escolar possui uma estrutura e um relacionamento entre os subsistemas significativamente diferentes do sistema industrial. Dentre essas idiossincrasias, ressaltamos:

\section{0 aspecto afetivo}

Em nenhuma atividade produtiva, o aspecto afetivo é tão significativo quanto o é na educação. A dimensão afetiva tem um papel enorme no despertar do potencial dos alunos e professores e, em conseqüência, na qualidade do ensino. Os laços que podem unir mestres e alunos vão além daqueles que ligam um produtor ao seu cliente mais simpático. Um mestre não "dá aula", ele influencia a formação de uma pessoa. Pais, alunos, mestres e a escola como um todo devem buscar um processo prazeroso de construção do conhecimento ou simplesmente não será possível alcançar a qualidade no ensino. Temos enfatizado esse aspecto porque, além de considerá-lo importante, ele é fundamental dentro da lógica do movimento da QT. A peculiaridade das relações professor $x$ aluno exigirá, sem qualquer sombra de dúvida, uma adaptação no conceito de cliente.

\section{0 aspecto da interdisciplinaridade}

Uma escola é uma organização que possui processos extraordinariamente interdependentes, mas, mesmo assim, deve preservar a iniciativa, a criatividade e a independência intelectual de todos os seus componentes. A interdisciplinaridade é um desafio para a padronização.

\section{A importância do compromisso social}

Toda empresa tem um compromisso com a sociedade, por exercer, de uma forma ou de outra, uma influência sobre o destino de todos. Essa influência, no con- 
texto industrial, é bastante variável, podendo ir desde uma presença marcante em toda a sociedade até níveis quase desprezíveis, tudo em função do momento e do tipo de atividade praticada. Uma empresa não se caracteriza normalmente pelo impacto social. O caso da educação é diametralmente oposto. É ela exatamente a parte do tecido social que recebe uma das mais amplas e contínuas delegações para influenciar o futuro da própria sociedade. Não importando se pública ou particular, em virtude de seu papel delegado, toda escola tem um forte dever com o social, compromisso esse que engloba a obrigação com um serviço de excelência e extensivo ao maior número possível de pessoas. Absolutamente nenhuma escola, em nenhum nível, em nenhum lugar da Terra pode ser encarada como um simples negócio. Essa mentalidade simplesmente desqualifica a organização para exercer a delegação de educar. Moldar o cidadão não pode ser encarado apenas como um negócio como outro qualquer. Pensando assim, estaríamos reduzindo os seres humanos no nível das "coisas" barganháveis e quantificáveis fiduciariamente. A educação exige os melhores sentimentos humanos. Nesse sentido, Herbert Feigl sintetiza uma frase atribuída a Einstein sobre a transcendência humana: "Se não houvesse essa iluminação interna no ser humano, o universo seria eternamente um monte de lixo". Negociar a educação é um dos mais lamentáveis e grosseiros erros que um administrador pode cometer. A escola só poderá alcançar a qualidade com uma dose de dedicação e compromisso que transcende o foco no resultado financeiro.

\section{Dificuldades conceituais}

Alguns pontos da filosofia da qualidade total devem ser traduzidos para o contexto da educação. O conceito do que venha a ser qualidade em educação, o conceito de cliente e o papel dos princípios da QT dentro da proposta pedagógica são pontos de discussão indispensável. Por outro lado, o conceito da busca da excelência, do atendimento de necessidades e expectativas dos envolvidos no processo e da qualidade de vida são conceitos em comum que facilitarão a tradução necessária.

\section{Uma alternativa de solução pela qualidade total}

A motivação básica para a adoção de uma solução para a educação via QT é a consciência do potencial da abordagem e da necessidade de mudança. Enquanto as antigas abordagens estiverem produzindo bons resultados, ninguém cogitará mudar. A QT é uma alternativa para os insatisfeitos! Enquanto a necessidade de mudança não for sentida, qualquer movimento rumo à QT será uma aventura teórica. Não se trata de difundir o medo do fim do mundo e sim de tomar consciência de que é indispensável abrir espaço para a criatividade e a flexibilidade, e que, sem compromisso com a busca constante da excelência, a contribuição organizacional e das pessoas pode não ser tão útil como seria desejável.

Nesse sentido, é indispensável buscar convencimento próprio de que:

- Na atualidade as organizações incapazes de lidar bem com mudanças e a gestão de atividades complexas perdem significativa parcela de sua "fitness", ficando mais vulneráveis às flutuações do cenário.

- Nesse processo de desajuste, mesmo organizações altamente competitivas e especializadas podem ser desestabilizadas, se não forem capazes de lidar com a mudança.

- Esse problema chegou na área da educação e promete causar profundas dificuldades às escolas.

- Dentro desse cenário de constantes pressões pela melhoria de desempenho e alteração nas regras de relacionamento cliente $x$ fornecedor, surgiu uma metodologia japonesa que foi capaz de lograr um razoável sucesso no sentido de direcionar a gestão das empresas.

- A solução japonesa foi aperfeiçoada à medida que as mudanças foram recrudescendo em velocidade e profundidade.

- Hoje a capacidade das abordagens baseadas na QT em lidar com a gestão de atividades complexas é comprovadamente alta.

- A principal vantagem desse metamodelo é sua enorme flexibilidade, o que facilita sobremaneira a autoadaptação a idiossincrasias específicas das organizações. 
- Trata-se de um metamodelo pronto para o desenvolvimento de altos patamares de produtividade; mas não é isso que caracteriza a abordagem. $\mathrm{O}$ que the confere poder é sua capacidade de comprometimento do fator humano e o enorme potencial adaptativo.

- O suporte ideológico do metamodelo é consistente com a ética educacional da perseguição da excelência pelo exemplo. A QT não busca o "primeiro lugar" e sim a excelência do trabaIho. A QT não objetiva "conquistar o mercado" e sim "encantar o cliente".

- Existe a possibilidade de utilização desse metamodelo com as adaptações necessárias no contexto educacional.

- No caso específico de "nossa" escola, essa abordagem poderia ser uma "boa idéia".

Confiança não se compra nem se vende. Para adquirir o convencimento da viabilidade da proposta da QT, a escola e seus agentes deverão procurar examinar programas semelhantes desenvolvidos por outras instituições. Isso poderá ser feito principalmente através de visitas, filmes ou exame da literatura disponível. A consultoria externa deve ser evitada nessa fase. Esse contato com a tecnologia da QT, sem qualquer monitoramento de consultores, será de uma utilidade fantástica quando chegar a ocasião de utilizar os serviços de uma consultoria. Mas, antes de pensar qualquer iniciativa para a QT, devemos estar convencidos da utilidade das seguintes palavras de Fritjord Capra: "Todos os problemas que testemunhamos hoje têm soluções, mas todas elas requerem uma mudança radical de nossa forma de pensar e agir".

As palavras de Capra ressaltam outro ponto de importância capital: Por onde começar? A qualidade deve ser algo vital, no sentido de redirecionar o pensamento e a atitude. Nesse caso procede a pergunta: Pensamento e atitude de quem? A resposta é óbvia: das pessoas. A qualidade depende das pessoas. A qualidade deve ser vital para as pessoas. A qualidade deve ser iniciada pelas pessoas. Não são máquinas, laboratórios ou salas de aula que irão promover a qualidade. Esses "insumos" permitem que a qualidade não se perca. É na mudança de atitudes e de desempenho em reação à qualidade que as coi- sas começam a acontecer. A qualidade de uma escola depende da parcela de qualidade de cada pessoa envolvida. É claro que é possível pensar um modelo específico para a QT na área educacional (Goldbarg, 1999), mas esse nível de detalhamento foge ao escopo do presente artigo. Antes de tudo, é fundamental examinar a proposta e estar convencido de que ela é viável.

\section{Conclusões}

Podemos destacar do debate exposto no presente artigo os seguintes pontos:

- A qualidade em educação não é um fim em si mesma; claramente possui elementos ideológicos voltados para a promoção dos quatro grandes ajustes organizacionais.

- Apesar desse conteúdo ideológico, não existe, todavia, a preponderância do engajamento político, e a dimensão da competência é predominante. Nem tudo é política para uma gestão pela QT do que botar os pés no chão, acenando para elementos de qualidade formal.

- Longe do messianismo, a face da conformidade e da adequação mostra que existem indicadores técnicos que também são importantes. A dimensão da racionalização normalmente não necessita decidir a cor de sua bandeira para funcionar, e isso faz parte da QT.

- As técnicas para dirigir a mudança rumo à QT no contexto educacional não podem ser simplesmente transplantadas do contexto empresarial; urge discuti-las e adaptá-las.

Talvez seja possível ignorar a QT e dar continuidade aos antigos projetos pedagógicos, na esperança de que algo mude apenas por insistência. Talvez possamos identificar causas externas e várias explicações que justifiquem essa nossa insistência. De fato, podemos fazer qualquer coisa, menos evitar a futura comparação com aqueles que resolverem utilizá-la. Quando o pensamento em crise busca uma saída para os velhos problemas da humanidade, a filosofia da qualidade total recupera conceitos adormecidos em nossos inconscientes; conceitos esquecidos de como poderíamos construir um mundo menos agressivo e mais humano apenas buscando o melhor dentro de cada um. 


\section{Referências bibliográficas}

ALBRECHT, K., LAWRENCE, B. J. Serviços com Qualidade : a vantagem competitiva. São Paulo: Makron Books, 1990.

AXLAND, S. Congressional Forum on Quality Education. Quality Progress, p. 67-68, Oct. 1992.

BEMOWSKI, K. Quality, American Style. Quality Progress, p. 65-68, fev. 1993.

BONILLA, J. A. Resposta à Crise : qualidade total e autêntica em bens e serviços. São Paulo : Makron Books, 1995.

BS7850. Total Quality Management. Part 1 : guide to management principles. (sic.)

CAPLAN, F. The National Educational Quality Initiative. Quality Progress, p. 63-65, Oct. 1992.

CHANG, Y. S., LABOVITZ, G., ROSANSKY, V. Qualidade na prática. Rio de Janeiro : Ed. Campus, 1995.

CHARNESS, M. P. Transition to Total Quality : a case study. In: QUALITY CONGRESS TRANSACTION. Nashville: ASQC, 1992. p. 258-264.

DAVIS, T. R. V. Balbridge winners link quality, strategy, and financial managements. Planning Review, Oxford, v. 6, n. 20, p. 36-40, 1992.

DEMING, W. E. Out of the crisis. Cambridge, Mass. : Mit, 1986. . Qualidade : a revolução da administração. Rio de Janeiro : Ed. Marques-Saraiva, 1990.

DRUCKER, P. F. Sociedade Pós-Capitalista. São Paulo : Pioneira, 1993.

FELLERS, K. G. Integrated QA Systems : marrying core QA systems and TQM philosophies. In: ANNUAL QUALITY CONGRESS, 49, 1995. Proceedings... ASQC, 1995. p. 597-600.

GARVIN, D. A. Gerenciando a Qualidade. Rio de Janeiro : Qualitymark, 1988.

GLASSER, W. The Quality School : managing students without coersion. New York : Harper Perennial, 1992.

GOLDBARG, M. C. A Terceira Onda da Qualidade : qualidade na educação. [S.I. : s.n.], 1999.

HARARI, O. Ten reasons why TQM doesn't work. Management Review, v. 1, n. 82 , p. 33-38, 1993.

HART, C., BOGAN, C. Balbridge : o que é o prêmio Balbridge e o que representa para as empresas. São Paulo : Makron Books, 1994.

HESSE, H. Jogos das Contas de Vidro. Rio de Janeiro : Record, 1943.

HITTMAN, J. A. TQM and CQI in Postsecondary Education. Quality Progress, p. 77-80, Oct. 1993.

ISHIKAWA, K. What is total quality control? The Japanese way. Englewood Cliffs : Prentice Hall, 1985.

JOHNSON, R. S. TQM : leadership for the quality transformation, Part 1. Quality Progress, p. 73-75, jan. 1993.

JUDD, D. K. The psychology of quality. In: ANNUAL QUALITY CONGRESS, 48, 1994. Proceedings... ASQC, 1994. p. 134-139. 
JURAN, J. M. Planning for Quality. Wilton, CT, USA : Juran Institute Inc, 1986.

KERN, J. P. Toward Total Quality Marketing. Quality Progress, p. 39-42, jan. 1993.

LAM, K. D., WATSON, F. D., SCHMIDT, S. R. Total Quality. Colorado Springs, Co. : Air Academy Press, 1991.

LEIGHTON, R. Restructuring for Quality Management. In: QUALITY CONGRESS TRANSACTIONS, Boston, 1993. Boston : ASQC, 1993. p. 64-70.

MCGREGOR, D. O lado humano da empresa. São Paulo : Martins Fontes, 1980.

MASLOW, A. H. Motivation and Personality. New York : Harper \& Row Publishers, 1970.

MURATA, K., HARRISON, A. Como fazer com que métodos japoneses funcionem no Ocidente. São Paulo : Makron Books, 1993.

NASCIMENTO, M. Qualidade como garantia de qualidade : é possível? Ensaio, v. 4, n. 1, p. 63-74, 1994.

PETERS, T. Prosperando no Caos. São Paulo : Harpa, 1989.

POPPER, K. R. Objective Knowledge : an evolutionary approach. Oxford : Clarendon Press, 1975.

RADFORD, G. S. The control of quality in manufacturing. Ne York : Ronald Press, 1922 apud GARVIN, D. A. Gerenciando a Qualidade. Rio de Janeiro : Qualitymark, 1988.

SALMON, V. R. Quality in American Schools. Quality Progress, p. 73- 75, Oct. 1993.

SAMUEL, M. S. Facilitation organizational change : leadership in a total quality environment. In: ANNUAL QUALITY CONGRESS, 48, 1994. Proceedings... ASQC, 1994. p. 242- 248.

SCHARGEL, F. P. Total Quality in Education. Quality Progress, p. 67-70, Oct. 1993.

SCHENEIDER, A. J. TQM and the financial function. Journal of Business Strategy, Boston, v. 5, n. 13 , p. $21-25,1992$.

SENGE, P. M. The fifth discipline : the art and practice of the learning organization. Doubleday Dell Publishing, 1990.

SHARMAN, G. When quality control gets in the way of quality. Wall Street Journal, 24 fev. 1992.

SHEWHART, W. A. The economic control of quality of manufactured products. Van Nostrand, 1931.

STOCKER, G. D. How to turn concepts into action. Quality Progress, p. 45-48, Jan. 1993.

WINDER, E. R. Fulfilling quality's five dimensions. In: QUALITY CONGRESS TRANSACTIONS, Boston, 1993. Boston : ASQC, 1993. p. 71-83.

Recebido em 21 de maio de 1998.

Marco César Goldbarg, doutor em Ciência na área de Sistemas e Computação pela Universidade Federal do Rio de Janeiro (UFRJ), é professor do Departamento de Informática e Matemática Aplicada da Universidade Federal do Rio Grande do Norte (UFRN). 


\section{Abstract}

The objective of this article is to debate the evolution of the concept of Total Quality and its application in the context of education. The article develops a historical analysis of the infolding of concepts associated with this approach, showing the current philosophical basis of the model and its potential to contribute to the creation of an educational process of quality. The evolution of quality is studied by means of a quantitative paradigm that gave rise to 3 waves of change. The study suggests various possibilities of contribution from the third wave model, not leaving, however, the possible resulting obstacles of the process. The conclusion shows the principle advantages and areas of weakness arising from the use of this model in education.

Key-Words: total quality; education 